\title{
Surface Complexation Modelling of Arsenic and Copper Immobilization by Iron Oxide Precipitates Derived from Acid Mine Drainage
}

\author{
Alba Otero-Fariña ${ }^{1}$, Raquel $\mathrm{Gago}^{2}$, Juan Antelo ${ }^{2, *}$, Sarah Fiol ${ }^{1}$, Florencio Arce ${ }^{1}$ \\ ${ }^{1}$ Department of Physical Chemistry, University of Santiago de Compostela, Avenida de las Ciencias s/n, 15782 Santiago de \\ Compostela, Spain. \\ ${ }^{2}$ Department of Soil Science and Agricultural Chemistry. University of Santiago de Compostela, Rúa Lope Gómez de Marzoa s/n, \\ 15782 Santiago de Compostela, Spain. \\ *juan.antelo@usc.es
}

\begin{abstract}
Acid mine drainage (AMD) constitutes a serious environmental problem in mining areas due to the acidification of soils and aquatic systems, and the release of toxic metals. Many of the pollutants that occur in AMD display a high affinity for the surfaces of the aluminium and iron oxides that are typically present in systems affected by AMD. This binding affinity reduces the mobility of trace metals and metalloids, such as copper and arsenic, thus helping to mitigate contamination of aquatic systems. In the present study, water samples and iron-rich bed sediments were collected in areas affected by copper mining activities. A loose ochre-coloured precipitate occurring on the banks of a river close to an abandoned tungsten and tin mine was also sampled. The composition of the precipitate was established, and adsorption experiments were performed with copper and arsenate ions to determine the ability of natural iron precipitates to reduce the concentration of these ions in solution. Surface complexation models provided a good description of the behaviour of natural iron oxides in terms of copper and arsenate retention. Use of this type of model enables prediction of the distribution of pollutants between the solid and solution phases and analysis of their mobility in relation to environmental conditions ( $\mathrm{pH}$, ionic strength, presence of competing species, etc.).
\end{abstract}

Keywords: Acid mine drainage, iron oxides, adsorption, trace elements, arsenic, surface complexation model.

\section{Resumen}

El drenaje ácido de mina (AMD) constituye un importante problema ambiental debido a la acidificación y la liberación de metales tóxicos que produce en el suelo y en los sistemas acuáticos próximos a las zonas mineras. Existe una elevada afinidad de muchos de los contaminantes presentes en AMD por la superficie de los óxidos de aluminio y hierro que son constituyentes típicos presentes en los sistemas afectados por AMD. Esta afinidad puede contribuir a atenuar la contaminación por metales traza y metaloides, tales como el cobre o el arsénico, en los sistemas acuáticos mediante la reducción de su movilidad. En el presente estudio se han recogido muestras de agua y de sedimentos con alto contenido en hierro en un área afectada por minería de cobre. Además, se recogió un precipitado amarillo de las orillas de un río situado en las proximidades de una antigua mina de wolframio y estaño. Estos precipitados fueron caracterizados para establecer su composición y se realizaron experimentos de adsorción con los iones cobre y arseniato para determinar la capacidad de los precipitados naturales de hierro para reducir su concentración en disolución. Se comprobó que los modelos de complejación superficial son capaces de reproducir el comportamiento de estos precipitados naturales en términos de retención de cobre y arseniato. Estos resultados permitirán predecir la especiación de estos contaminantes en presencia de óxidos de hierro formados en ambientes afectados por AMD y analizar su movilidad en función de las condiciones (pH, fuerza iónica, presencia de especies que compitan, etc.). 
Palabras clave: Drenaje ácido de mina, óxidos de hierro, adsorción, elementos traza, arsénico, modelo de complejación superficial.

\section{Introduction}

Mining and processing of mineral ores constitute major sources of contamination in soils, sediments and aquatic systems worldwide. Oxidation of sulphide minerals (mainly iron sulphides such as pyrite, arsenopyrite and chalcopyrite) leads to acid mine drainage (AMD), which causes acidification of surface waters and the release of trace elements into soils and water systems (Bigham and Nordstrom, 2000; Olías et al., 2006; Nordstrom, 2011). Weathering of iron sulphide minerals produces large amounts of secondary iron precipitates, which may contribute to the removal and immobilization of trace elements present in systems affected by AMD (Regenspurg and Peiffer, 2005; Schroth and Parnell, 2005; Acero et al., 2006; Burgos et al., 2012).

The nature and composition of the secondary iron precipitates present in AMD systems is mainly determined by the concentration of sulphate ions and the $\mathrm{pH}$ of the aqueous phase (Bigham and Nordstrom, 2000). Thus, schwertmannite, $\mathrm{Fe}_{8} \mathrm{O}_{8}(\mathrm{OH})_{6}\left(\mathrm{SO}_{4}\right)_{2}$, is commonly formed at $\mathrm{pH} 3.0-4.0$, while jarosite, $\mathrm{KFe}_{3}(\mathrm{OH})_{6}\left(\mathrm{SO}_{4}\right)_{2}$, is usually formed at lower $\mathrm{pH}$ values. At circumneutral $\mathrm{pH}$ values $(6-8)$, ferrihydrite or hydrous ferric oxide, $\mathrm{Fe}(\mathrm{OH})_{3}$, and goethite, $\alpha-\mathrm{FeOOH}$, are the predominant secondary minerals present in the system. The precipitates formed in AMD systems usually contain different secondary iron minerals; some of these mineral phases change within weeks or months as forms such as schwertmannite are metastable and can undergo phase transformation to more crystalline mineral phases (Bigham et al., 1996; Regenspurg et al., 2004).

Study of the surface reactivity of the secondary iron minerals occurring in AMD has been of great concern in the last decade. These minerals are naturally occurring attenuators for species such as arsenic and trace metals that may be present in these systems. Many authors have attempted to elucidate the mechanism of such attenuation in natural precipitates and synthetic analogues (Jönsson et al., 2006; Burton et al., 2009; Paikaray et al., 2011; Antelo et al., 2012; Paikaray et al., 2012; Maillot et al., 2013). Immobilization of trace metals and metalloids by these iron minerals is known to take place via surface adsorption and coprecipitation (Martínez and McBride, 2001; Lee et al., 2002; Antelo et al., 2013). Iron oxide minerals usually have a high specific surface area and variable surface charge, properties that may favour the efficient retention of both anions and cations in systems affected by AMD. Schwertmannite and jarosite may decrease the mobility of trace elements by coprecipitation during formation of the iron mineral oxide or by surface adsorption onto the pre-existing minerals. Moreover, if anionic species such as arsenate are present in the system, the immobilization mechanism may involve anion exchange with the sulphate groups present in the crystalline structure of these minerals (Carlson et al., 2002; Burton et al., 2009; Antelo et al., 2012).

Numerous adsorption studies on synthetic analogues have been reported in the literature; however, this does not guarantee that the analogues are relevant or behave identically in natural systems. The data obtained in such studies do not reflect the fact that natural oxides are formed in multicomponent systems (e.g. AMD usually contains Fe, $\mathrm{S}$, As and multiple trace metals). Therefore, coprecipitation is likely to occur and may lead to the formation of different secondary minerals and to the presence of impurities in the minerals. In order to determine the efficiency of secondary iron minerals as natural contaminant scavengers, as well as the immobilization mechanism involved, it is important to identify the reactions that the mineral adsorbent undergoes following changes in the physico-chemical properties of the system, e.g. $\mathrm{pH}$, ionic strength and temperature. Thermodynamic description of the surface reactivity of iron oxides is crucial for developing surface complexation models that predict the fate of environmentally relevant species. Therefore, detailed description and quantification of adsorption reactions are necessary to predict the mobility and bioavailability of trace elements in soils and aquatic systems. In the present paper, we investigate the adsorption of arsenate and copper on natural iron oxide precipitates collected from aquatic systems affected by AMD. The aim of the study was to improve our understanding of the processes controlling the adsorption of trace elements and to assess the capacity of surface complexation models developed for synthetic analogues to predict the behaviour of arsenate and copper in the presence of natural iron precipitates.

\section{Materials and methods}

\subsection{Field sites and sample collection}

Iron oxide precipitates were collected in areas close to the abandoned Touro copper mine (NW Spain, $42^{\circ} 52^{\prime} 34^{\prime \prime}$ $\mathrm{N} 8^{\circ} 20^{\prime} 40^{\prime \prime} \mathrm{W}$ ) and the abandoned Fontao tungsten and tin mine (NW Spain, 42 $45^{\prime} 16^{\prime \prime} \mathrm{N} 8^{\circ} 13^{\prime} 55^{\prime \prime} \mathrm{W}$ ) between September and October 2013. In the area encompassing the Touro mine, which was exploited between 1974 and 1988, the geological substrate predominantly consists of amphibolite, with large quantities of metal sulphides such as pyrite and chalcopyrite. Weathering and oxidative dissolution of these minerals has led to the release of AMD to the neighbouring streams, producing frequent episodes of extreme acidity and mobilization of toxic elements in 
the surface waters (Álvarez et al., 1993). During the last 15 years, remediation processes and environmental monitoring have been conducted at the most critical sites (Álvarez et al., 2011). The area encompassing the abandoned Fontao mine, which was exploited between 1934 and 1973, includes numerous $\mathrm{Sn}-\mathrm{W}$ quartz veins, with cassiterite and wolframite as the main ore minerals and with a significant presence of sulphide minerals such as pyrite, chalcopyrite and arsenopyrite.

Two streams were selected as sampling sites for the present study: the Portapego stream (T-PO), which flows from the Touro mine to the river Lañas, and the Orza stream (F-OR), which is close to the Fontao mine. At sampling site T-PO (Figure 1a), iron-rich AMD bed sediments were collected from the upper $10 \mathrm{~cm}$. At sampling site F-OR (Figure 1b), loose ochre-coloured precipitates were collected from the banks of the stream. Both samples were kept in polyethylene flasks and stored at $4{ }^{\circ} \mathrm{C}$ in darkness until analysis, to prevent changes in the chemical and mineralogical composition. The T-PO sediment sample was air-dried, sieved $(<50 \mu \mathrm{m})$ and ground to a fine powder for the laboratory study. The F-OR precipitate was washed carefully with ultrapure water and centrifuged for 20 minutes at $12000 \mathrm{rpm}$ to remove soluble ionic species and other impurities, and the solid was then re-suspended in ultrapure water. The conductivity of the supernatant was measured to ensure that no ionic species were present. A fraction of the final suspension was freeze-dried to obtain solid samples for characterization of the iron precipitates, while the remaining fraction was maintained as a suspension for the adsorption experiments.

Water samples were also collected at both sampling sites to assess the physico-chemical properties and the degree of metal contamination. In the field, these samples were immediately filtered through $0.45 \mu \mathrm{m}$ Millipore filters and subsamples were acidified with $1 \% \mathrm{HNO}_{3}$ for metal analysis. The $\mathrm{pH}$, temperature, electrical conductivity (EC) and dissolved oxygen were measured in situ. Water samples were transported to the laboratory and stored at $4{ }^{\circ} \mathrm{C}$ until analysis.

\subsection{Characterization of iron oxide precipitates}

Powder X-ray diffraction (XRD) patterns were obtained (in a Phillips PW1710 diffractometer) by measuring the scintillation response to $\mathrm{CuK} \alpha$ radiation over the range $15^{\circ}$ to $70^{\circ} 2 \theta$, with a step size of $0.02^{\circ}$ and a counting time of 6 seconds per step. XRD patterns of synthetic analogues (goethite, schwertmannite and ferrihydrite), previously prepared in the laboratory by the methods recommended in the literature (Cornell and Schwertmann, 1996), were also obtained for comparative purposes. ATR-FTIR spectra of the precipitates, synthetic schwertmannite and $\mathrm{K}_{2} \mathrm{SO}_{4}$, were recorded in a JASCO FTIR-4200 spectrophotometer. The powdered samples were mixed homogeneously and placed on a ZnSe ATR crystal plate (Pike MIRacle Single Reflection ATR). The spectra obtained corresponded to at least 50 co-added scans with a resolution of $4 \mathrm{~cm}^{-1}$. The IR spectra of the sulphate bands were measured in the range $1250-900 \mathrm{~cm}^{-1}$. The chemical composition of the iron oxide precipitates was determined after digestion of $0.05 \mathrm{~g}$ of the precipitate in $50 \mathrm{~mL}$ of $6 \mathrm{M} \mathrm{HCl}$. The concentrations of $\mathrm{Fe}, \mathrm{Al}, \mathrm{Mn}, \mathrm{As}, \mathrm{Cu}, \mathrm{Ni}, \mathrm{Pb}$ and $\mathrm{Ni}$ were measured in the digested samples by inductively coupled plasma optical emission spectroscopy (ICP-OES, PerkinElmer Optima 3300DV). The sulphate concentration was determined by a turbidimetric method (Clesceri et al., 1998), in a Jasco V-530 UV/VIS spectrophotometer. The poorly crystalline iron oxides were extracted by ammonium oxalate for quantification (McKeague and Day, 1966). Operationally, the difference between the total digestion and the oxalate extraction enables distinction between the poorly crystalline forms (schwertmannite or ferrihydrite) and the more crystalline forms (goethite). The iron precipitates were

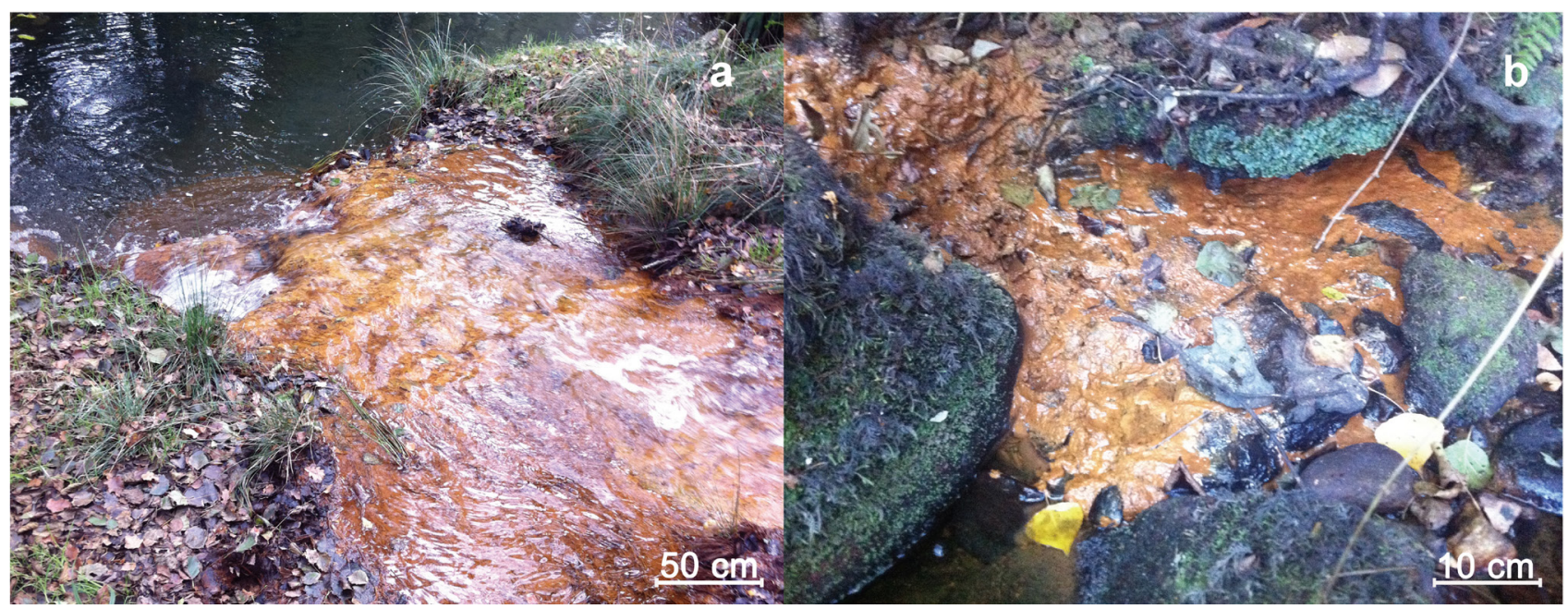

Figure 1. Photographs of the sampling sites. a) ochreous precipitates on the Portapego stream bed sediments, and b) loose precipitate in the Orza stream. 
extracted with $0.2 \mathrm{M}$ acid ammonium oxalate ( $\mathrm{pH} 3.0$ ) in the dark for $4 \mathrm{~h}$ at a solid/solution ratio of $10 \mathrm{~g} / \mathrm{l}$. Dissolved Fe and $\mathrm{Al}$ in the oxalate extracts were measured by ICP-OES. The BET specific surface area (SSA) was measured by $\mathrm{N}_{2}$ adsorption in a Micromeritics ASAP 2000 analyzer (V3.03).

Trace metal concentrations in the water samples were analysed by ICP-OES, while the concentrations of major cations ( $\mathrm{Fe}, \mathrm{Al}, \mathrm{Ca}, \mathrm{Mg}, \mathrm{Na}$, and $\mathrm{K}$ ) were determined by atomic absorption spectroscopy (AAS, PerkinElmer 1100B). The concentrations of sulphate, nitrate and chloride were determined by standard methods (Clesceri et al., 1998).

\subsection{Arsenate and copper adsorption on AMD precipitates}

The effect of $\mathrm{pH}$ on the adsorption of both arsenate and copper was evaluated in batch experiments. Suspensions of the AMD precipitates $(1 \mathrm{~g} / 1$ for the arsenate experiments, and $0.5 \mathrm{~g} / \mathrm{l}$ for the copper experiments) were prepared in 20 $\mathrm{ml}$ of $\mathrm{KNO}_{3}$ as the inert electrolyte. All experiments were carried out with initial arsenate concentrations of 285 and $570 \mu \mathrm{M}$ or with initial copper concentrations of 100 and 500 $\mu \mathrm{M}$. Adequate volumes of stock solutions of arsenate $(0.04$ $\left.\mathrm{M} \mathrm{KH}_{2} \mathrm{AsO}_{4}\right)$ and copper $\left(0.1 \mathrm{M} \mathrm{Cu}\left(\mathrm{NO}_{3}\right)_{2}\right)$ were added to produce the desired concentrations on the suspensions of AMD precipitate. The $\mathrm{pH}$ of the suspensions was adjusted to within $\mathrm{pH} 3-10$ by addition of $0.1 \mathrm{M} \mathrm{HNO}_{3}$ or $0.1 \mathrm{M}$ $\mathrm{KOH}$. This broad $\mathrm{pH}$ range was selected to yield measurable adsorption of both arsenate (relatively low $\mathrm{pH}$ values) and copper (relatively high $\mathrm{pH}$ values) and to enable comparison of ion adsorption on the precipitates with that reported for synthetic analogues. The samples were shaken for 24 hours in a reciprocal shaker (IKA Labortechnik H5501 Shaker), as preliminary experiments indicated that shorter contact times were sufficient to ensure that equilibrium was achieved. During the equilibration period, the $\mathrm{pH}$ was measured periodically and, when necessary, readjusted by adding small amounts of $\mathrm{HNO}_{3}$ or $\mathrm{KOH}$ solutions. Special care was taken to prevent the presence of $\mathrm{CO}_{2}$, by maintaining the suspensions in $\mathrm{N}_{2}$ atmosphere.

In order to analyse the effect of the ionic strength on the adsorption of arsenate to the AMD precipitates, additional experiments were carried out at ionic strength $0.01,0.1$, and $0.5 \mathrm{M}$ in $\mathrm{KNO}_{3}$. Batch experiments were carried out as described above, i.e. arsenate was added (initial concentration of $570 \mu \mathrm{M}$ ) to $20 \mathrm{ml}$ of the AMD suspension $(1 \mathrm{~g} / \mathrm{l})$, the $\mathrm{pH}$ was adjusted (to within $\mathrm{pH} 4-10$ ) with 0.1 $\mathrm{M} \mathrm{HNO}_{3}$ or $\mathrm{KOH}$, and the samples were shaken for 24 hours until equilibrium was achieved.

Once equilibrium was reached, the samples were filtered through $0.45 \mu \mathrm{m}$ Millipore membrane filters, and the concentration of arsenate or copper was measured in the filtrate. The concentration of arsenate was determined by the colorimetric method proposed by Lenoble et al. (2003), and the concentration of copper was determined by ICP-OES. The concentration of the adsorbed ion was then calculated as the difference between the initial amount added to the suspension and the final amount remaining in solution.

Each experiment was carried out in duplicate (at least) to confirm the reproducibility. All chemicals were of Merck pro analysis grade quality and the water used in the experiments was ultrapure and $\mathrm{CO}_{2}$ free. Polyethylene flasks were used to prevent contamination of the AMD precipitates with silicate, and the temperature was maintained at $25 \pm 1{ }^{\circ} \mathrm{C}$ in all adsorption experiments.

\subsection{Surface complexation modelling}

Various geochemical and surface complexation models (SCMs) have been developed in the last few decades to elucidate the processes that control the mobility and bioavailability of chemical species in soil and aquatic systems (Groenenberg and Lofts, 2014). Models of the solid/solution interface are powerful tools that can help unravel the mechanisms controlling ion adsorption and predict the reactivity of the charged mineral surfaces present in soils and sediments. These models are generally divided into two main parts: i) one part that describes the solid surface, including the type and reactivity of surface sites, the species adsorbed, the surface charge, etc.; and ii) another part describes the electrostatics, charge distribution and potential decay at the solid/solution interface. Among many SCMs that have been applied so far, the generalized two-layer (GTL) model, the triple layer (TLM) model and the charge distribution (CD) model have become the most popular for describing the surface reactivity of crystalline and amorphous iron oxides such as goethite and ferrihydrite (Davis et al., 1978; Dzombak and Morel, 1990; Hiemstra and van Riemsdijk, 1996). However, use of these models to describe the adsorption behaviour of iron precipitates present in AMD is rather complicated due to the difficulties that exist in characterizing these natural oxides. AMD precipitates may comprise different crystalline and amorphous iron oxides, depending on the physico-chemical conditions of the system, and may contain impurities not present in the synthetic analogues.

In the present study, arsenate and copper adsorption data for the AMD precipitates were initially modelled using the GTL model, which is less mechanistic and structurallybased than other SCMs. The solid/solution interface is simplified to a surface plane and a diffuse double layer that neutralizes the surface charge. This conceptual interface structure does not distinguish inner- and outer-sphere complexes. More realistic SCMs consider a diffuse double layer with at least one Stern plane, resulting in a basic or an extended Stern layer model to describe the solid/solution interface. The simplicity of the GTL model results in fewer adjustable parameters in the modelling calculations, but may enable accurate description and prediction of the adsorption behaviour of anions and cations over a wide range of conditions (Mathur and Dzombak, 2006; Karamalidis and Dzombak, 2010). A detailed description of the SCM, including its formulation for ion adsorption, has been 
reported by Dzombak and Morel (1990) for amorphous iron oxides. Briefly, the surface groups $(\equiv \mathrm{FeOH})$ behave as a diprotic acid and the surface charge behaviour is described using a 2-pK approach $\left(\log \mathrm{K}_{\mathrm{H} 1}, \log \mathrm{K}_{\mathrm{H} 2}\right)$. An electrostatic term that accounts for the coulombic interactions is included in the model in order to obtain intrinsic constants that do not change with surface charge.

As a modelling exercise, the adsorption data were also simulated using the CD model, which assumes a more realistic approach to describe the solid/solution interface and the surface reactions occurring. The contribution of anion exchange reactions with the sulphate ions present in the structure of the precipitates was considered. The $\mathrm{CD}$ model considers separate surface groups $(\equiv \mathrm{FeOH}$ and $\equiv \mathrm{Fe}_{3} \mathrm{O}$ ) and specific surface complexation reactions. Protons were assumed to bind to $\equiv \mathrm{FeOH}$ and $\equiv \mathrm{Fe}_{3} \mathrm{O}$ groups, while arsenate and copper ions were assumed to bind only to $\equiv \mathrm{FeOH}$ groups. Protonation of the surface groups was described using a 1-pK approach, while Pauling's valence bond concept was used to determine the charge distribution of ions over the coordinating ligands. The $\mathrm{CD}$ model also considers a spatial distribution of the charge at the solid/ solution interface. Therefore, the charge is distributed in 3 electrostatic planes: i) the 0 -plane, corresponding to the mineral surface and where the charged surface groups are located; ii) the 1-plane, which divides the Stern layer; and iii) the 2-plane, which separates the Stern layer from the diffuse layer. The charge of inner-sphere complexes is distributed between the 0 -plane and 1-plane, while outer-sphere complexes are assumed to be single point charges and are usually situated in the 1-plane (separated from the surface by water molecules). The interfacial charge distribution of a surface complex between the electrostatic planes can be calculated using the Brown bond valence concept.

Modelling calculations for the Generalized Two-Layer model were carried out using Visual MINTEQ (Gustafsson, 2012). The parameters required for describing the adsorption of both arsenate and copper were optimized by a trial-anderror procedure. Constants were systematically varied in order to minimize the root-mean-square error in the adsorbed fraction. CD model simulations were conducted with the Equilibrium Calculation of Speciation and Transport (ECOSAT) program (Keizer and van Riemsdijk, 1998).

\section{Results and Discussion}

\subsection{Water chemistry}

Sampling site T-PO is severely affected by AMD as indicated by the chemical composition and physicochemical properties of the water samples, i.e. low $\mathrm{pH}$, high electrical conductivity and high concentrations of $\mathrm{Fe}$ and $\mathrm{SO}_{4}$ (Table 1). Oxidation of sulphide minerals releases high concentrations of sulphate and Fe ions (Nordstrom,
Table 1. Chemical analysis of the water samples from the Portapego (T-PO) and Orza (F-OR) streams.

\begin{tabular}{cccccccccc}
\hline Site & $\mathbf{p H}$ & $\begin{array}{c}\mathbf{E C} \\
(\mu \mathrm{S} / \mathrm{cm})\end{array}$ & $\mathbf{F e}$ & $\mathbf{A l}$ & $\mathbf{C u}$ & $\begin{array}{c}\mathbf{Z n} \\
(\mathrm{mg} / \mathrm{L})\end{array}$ & $\mathbf{N i}$ & $\mathbf{S O}_{4}$ & $\mathbf{C l}$ \\
\hline$T-P O$ & 3.13 & 902 & 47.5 & 5.1 & 0.04 & 0.13 & 0.09 & 273.2 & 190 \\
$F-O R$ & 7.74 & 160.4 & 0.06 & 0.02 & $<0.01$ & 0.01 & $<0.02$ & 11.1 & 9.9 \\
\hline
\end{tabular}

2011). The concentrations of $\mathrm{Fe}$ were lower than expected, indicating that most of the dissolved Fe was precipitated, via hydrolysis reactions, to form iron oxide minerals (Burgos et al., 2012). The bed sediments were coated with reddishyellowish iron precipitates (Figure 1a). Moreover, the concentrations of dissolved trace metals in samples from the Portapego watercourse were higher than the recommended limits for drinking water, established by the EU (European Commission, 1998). However, the newly formed iron oxides can easily remove trace metals from solution either by coprecipitation or by adsorption processes.

The results obtained for the Orza stream indicate that the AMD had only a slight effect on the water quality. The $\mathrm{pH}, \mathrm{EC}$ and concentrations of major elements were within the usual ranges for uncontaminated surface waters. The concentrations of most of the trace elements analysed were below detection limits, and the concentrations of $\mathrm{Cu}$ and $\mathrm{Zn}$ were $2-3$ orders of magnitude lower than those found in the Portapego stream. Unlike in T-PO, As was detected in F-OR, [As] = $17.2 \mu \mathrm{g} / 1$, indicating potential enrichment of the stream sediments with arsenic-rich mineral forms.

\subsection{Characterization of iron oxide precipitates}

The iron oxides present in sampling sites T-PO and F-OR were characterized by XRD and the diffractograms were compared with those obtained for the synthetic analogues. The X-ray diffractograms revealed significant differences in the mineralogy of the iron oxides collected at both sampling sites (Figure 2). The dominant mineral phase in sample F-OR is an amorphous iron oxide that resembles ferrihydrite. The diffractogram shows a broad band at $\sim 35^{\circ}$ and a low intensity band at higher $2 \theta, \sim 60-$ $65^{\circ}$. No additional peaks indicating the presence of goethite or schwertmannite were found for this sampling site. The absence of schwertmannite phases confirms that sampling site F-OR was not greatly affected by AMD discharges from the nearby abandoned tungsten-tin mine. Sample T-PO presents several peaks that can be assigned to the presence of goethite. According to Asta et al. (2010), the weak XRD peaks of schwertmannite can be masked by the peaks of more crystalline phases, which are usually of higher intensity. The XRD data do not clarify whether goethite is the only iron oxide phase formed or schwertmannite is also present. The metastable character of schwertmannite particles favours phase transformation to goethite or other iron crystalline phase within weeks or months, depending on the physico-chemical conditions and water chemistry 


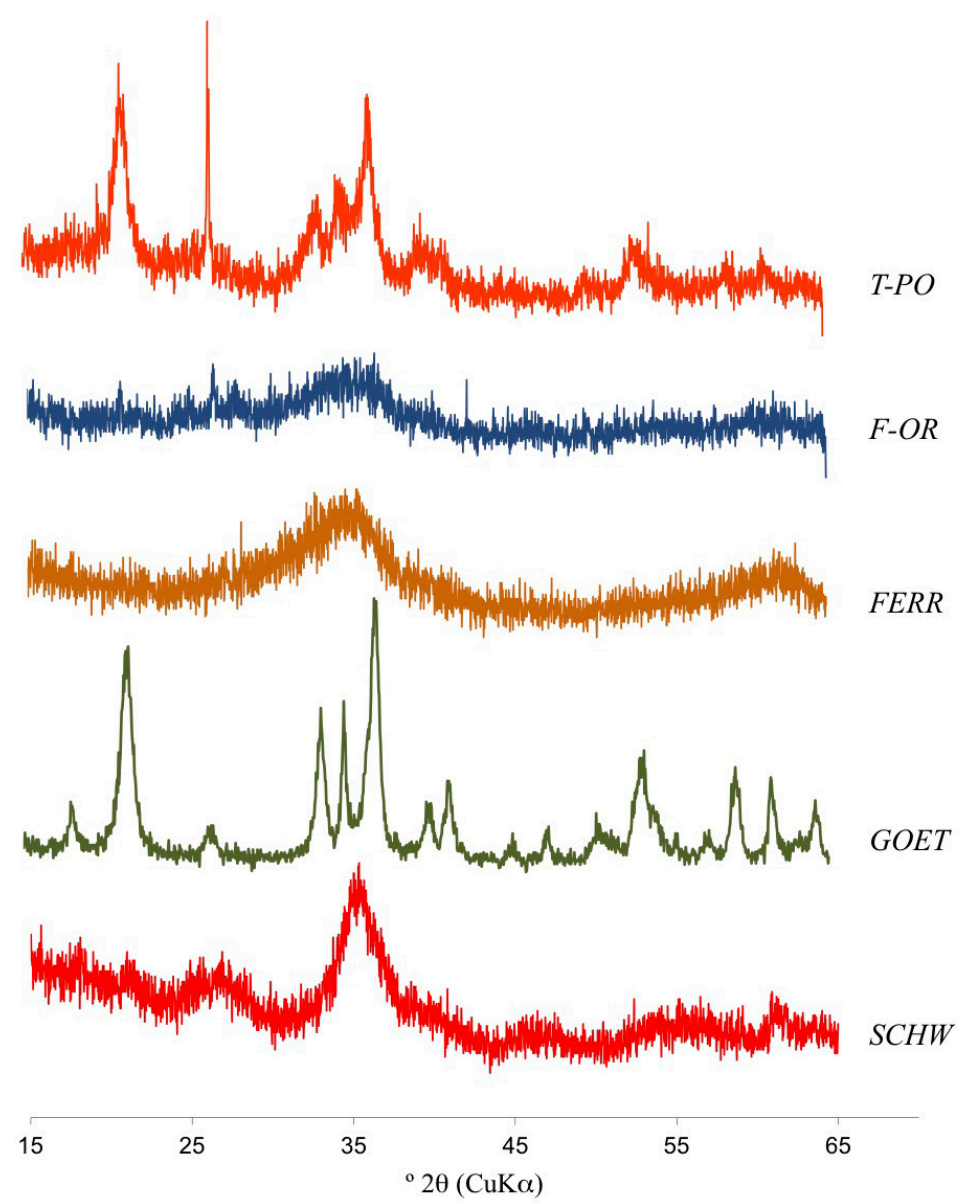

Figure 2. X-ray diffractograms of the iron oxide precipitates T-PO and F-OR and of goethite (GOET), ferrihydrite (FERR) and schwertmannite (SCHW).

of the AMD system. Studies by Kumpulainen et al. (2007) and Peretyazko et al. (2009) on the mineralogy of AMD precipitates showed seasonal variations in the occurrence of both mineral phases. Schwertmannite was the dominant mineral present during spring, but it was then partially transformed to goethite during the warmer summer months because of changes in the water chemistry.

As already pointed out, poorly crystalline oxides, such as schwertmannite, may be difficult to detect by XRD in mixtures containing more crystalline forms. Nevertheless, on the basis of the concentration of Fe $(4.41 \mathrm{mmol} / \mathrm{g})$ measured in the ammonium oxalate extract, the amount of poorly crystalline forms exceeded the amount of the more crystalline forms. Partition of Fe between the oxalate and total extractable phases showed that $77.9 \%$ of the total $\mathrm{Fe}$ corresponded to poorly crystalline oxides (schwertmannitelike). According to the concentrations of sulphate measured in the digested samples (Table 2), sample T-PO contained a large amount of sulphate in its crystalline structure (or adsorbed to the mineral surface). The ideal chemical formula for schwertmannite is $\mathrm{Fe}_{8} \mathrm{O}_{8}(\mathrm{OH})_{8-2 \mathrm{x}}(\mathrm{SO} 4)_{\mathrm{x}}$, where $x$ ranges between 1 and 1.75. Although the sulphate content range proposed by Bigham et al. (1990) is widely accepted, a recent study by Caraballo et al. (2013) pointed out that the proposed range was obtained with the data available in the 1990s. However, when more recent information on the chemical composition of natural schwertmannite particles is taken into account, a wider range $(0.52-1.84)$ is obtained. The concentration of $\mathrm{SO}_{4}$ measured after complete dissolution of the T-PO precipitate (Table 2) is within the latter range. The Fe: $\mathrm{SO}_{4}$ molar ratio, which is commonly used to characterize the composition of schwertmannite particles, is 6.14. This molar ratio falls within the range proposed for ideal schwertmannite $(4-8)$ and also within the broader range proposed by Caraballo et al. (2013), for natural schwertmannite samples $(3.77-15.53)$. These results suggest the presence of schwertmannite particles in the sample collected at the T-PO site. The concentration of trace elements in the AMD precipitate was low (Table 2) or negligible. Although a higher concentration of $\mathrm{Cu}$ may be expected, the measured value is comparable with the values obtained by Kumpulainen et al. (2007) for AMD precipitates collected from the surroundings of copper mines.

The concentrations of $\mathrm{Fe}$ and $\mathrm{SO}_{4}$ in sample F-OR were higher than those in sample T-PO. The Fe: $\mathrm{SO}_{4}$ molar ratio was 2.84 , which is outside the range proposed by Caraballo 
Table 2. Concentration of major and trace elements in the iron precipitates collected from the Portapego and Orza streams.

\begin{tabular}{cccccccccc}
\hline Site & $\mathbf{F e}_{\text {tot }}$ & $\mathbf{F e}_{\text {oxa }}$ & $\mathbf{S O}_{4}$ & $\mathbf{A l}$ & $\mathbf{C u}$ & $\mathbf{Z n}$ & $\mathbf{M n}$ & $\mathbf{N i}$ & As \\
& & & & \multicolumn{7}{c}{$(\mathrm{mmol} / \mathrm{g})$} & & \\
\hline$T-P O$ & 5.66 & 4.41 & 0.92 & 0.49 & $4.30 \cdot 10^{-3}$ & $4.59 \cdot 10^{-3}$ & $1.62 \cdot 10^{-3}$ & $3.75 \cdot 10^{-4}$ & $<1.00 \cdot 10^{-4}$ \\
$F-O R$ & 7.56 & 7.19 & 2.66 & 1.05 & $2.22 \cdot 10^{-3}$ & $2.16 \cdot 10^{-3}$ & 0.06 & $<3.00 \cdot 10^{-4}$ & $<1.00 \cdot 10^{-4}$ \\
\hline
\end{tabular}

Abbreviations: tot $=$ total digestion; oxa $=$ ammonium oxalate extraction.

et al. (2013), confirming the XRD results indicating the absence of schwertmannite particles in the F-OR precipitate. The high concentration of sulphate may be associated with surface adsorption to the newly formed precipitate resembling ferrihydrite. Iron oxides such as goethite and ferrihydrite are known to act as scavengers for dissolved species and may immobilize sulphate ions under suitable conditions, i.e. $\mathrm{pH}<7.0$ (Fukushi et al., 2013). The Fe extracted with ammonium oxalate accounts for almost $95 \%$ of the total iron content, indicating that ferrihydrite (or hydrous iron oxide) is the main mineral phase present in the F-OR precipitate. The concentration of the trace elements analysed was rather low, which was expected because, as stated above, this sampling site was not greatly affected by AMD.

Figure 3 shows the ATR-FTIR spectra obtained for the iron precipitates and the synthetic analogues. Data analysis focuses on the $1200-900 \mathrm{~cm}^{-1}$ region, in which bands associated with sulphate vibrations (S-O stretching bands) are usually found. Bands at a lower wavenumber (represented by the dotted lines shown in Figure 3) can be assigned to $\mathrm{Fe}-\mathrm{O}$ stretching. The number of peaks observed between 1200 and $900 \mathrm{~cm}^{-1}$, along with their relative intensity and position, are characteristic of the molecular symmetry and coordination of sulphate ions (Zhang and Peak, 2007). Clear differences between samples are observed. In the case of sample T-PO, three bands were detected in this region, which might be assigned to asymmetric stretching $\left(v_{3}\right)$ bands $\left(\sim 1096\right.$ and $\left.\sim 1032 \mathrm{~cm}^{-1}\right)$ and to a symmetric stretching $\left(v_{1}\right)$ band $\left(\sim 974 \mathrm{~cm}^{-1}\right)$. These bands, previously identified in different studies involving synthetic (Peak et al., 1999) and natural (Kumpulainen et al., 2007) iron oxides, are indicative of the presence of adsorbed or structural sulphate groups. Splitting into separate $v_{3}$ bands is common for iron oxides formed at low pH (Fukushi et al., 2013; Tresintsi et al., 2014) and was also observed in the synthetic schwertmannite analysed $(\sim 1110$ and $\sim$ $\left.1066 \mathrm{~cm}^{-1}\right)$. This suggests that sulphate groups are present as inner-sphere complexes on the mineral surface and on the crystalline structure. If outer-sphere complexes were dominant, a broader band (with no peak splitting) would be observed at $1100 \mathrm{~cm}^{-1}$, resembling the FTIR spectra of free sulphate groups. In the case of the F-OR precipitate, these bands were not present, which suggests that sulphate groups were not adsorbed as inner- or outer-sphere complexes. Considering the results reported by Kumpulainen et al.
(2007), iron oxides collected from mine soils of neutral $\mathrm{pH}$ (as in the present case) do not display S-O stretching bands. Therefore, the broad band at $945 \mathrm{~cm}^{-1}$ could be assigned to $\mathrm{Fe}-\mathrm{O}-\mathrm{Si}$, indicating co-precipitation or adsorption of silicate groups. However, the nature of sulphate groups present in the F-OR precipitates and detected by analysis of the chemical composition remains unresolved. Further analysis using more advanced techniques, such as X-ray absorption spectroscopy or X-ray photoelectron spectroscopy, should be carried out to clarify the nature and the location of the sulphate groups present in the iron precipitates under study.

The SSA of the T-PO precipitate determined by the BET method was $127 \mathrm{~m}^{2} / \mathrm{g}$, which falls within the range for schwertmannite particles $\left(100-300 \mathrm{~m}^{2} / \mathrm{g}\right)$ reported by Bigham et al. (1990). Slow crystallization may favour higher surface area values for schwertmannite particles (Regenspurg et al., 2004). On the other hand, lower SSA (< $100 \mathrm{~m}^{2} / \mathrm{g}$ ) would be expected if goethite were the dominant mineral phase of the T-PO precipitate. The SSA obtained for the F-OR precipitate was $216 \mathrm{~m}^{2} / \mathrm{g}$, which is similar to the surface area determined for synthetic ferrihydrite by the same method (Antelo et al., 2010; Zhu et al., 2011).

\subsection{Arsenate removal by AMD precipitates}

The adsorption of arsenate as a function of $\mathrm{pH}$ and ionic strength is shown in Figure 4, along with the GTL modelling predictions. Adsorption decreased gradually and continuously as $\mathrm{pH}$ increased in the range $3-10$. This decrease can be explained by the fact that the surface of the iron oxide becomes negatively charged (or less positively charged) as the $\mathrm{pH}$ increases. Greater electrostatic repulsion will occur towards the less protonated arsenate species that predominate at the highest $\mathrm{pH}$ values, favouring the mobilization of arsenate. In addition to surface complexation with the iron hydroxyl groups present at the mineral surface, adsorption of arsenate on sample T-PO, which can be defined as a mixture of goethite and schwertmannite particles, involves anion exchange reactions with the sulphate ions present in the schwertmannite crystalline structure. Evidence for anion exchange reactions involving sulphate release from schwertmannite has been obtained in different studies (Burton et al., 2009; Antelo et al., 2012). The exchange coefficient $\left(\mathrm{R}_{\mathrm{ex}}\right)$ values obtained in those studies were $\mathrm{pH}$ dependent and always lower than $0.5 \mathrm{~mol} \mathrm{SO}_{4} / \mathrm{mol}$ $\mathrm{AsO}_{4}$. An exchange coefficient below 1 can be interpreted 
as being due to partial substitution of the structural sulphate by the arsenate ions and the co-existence of both adsorption mechanisms. However, as the $\mathrm{pH}$ increases, structural sulphate may be substituted by $\mathrm{OH}^{-}$ions and surface complexation with the iron hydroxyl groups will become the main adsorption mechanism. Unfortunately, in the present study sulphate concentration was not measured after arsenate adsorption and therefore the exchange coefficients cannot be calculated.

For both precipitates, the effect of ionic strength on

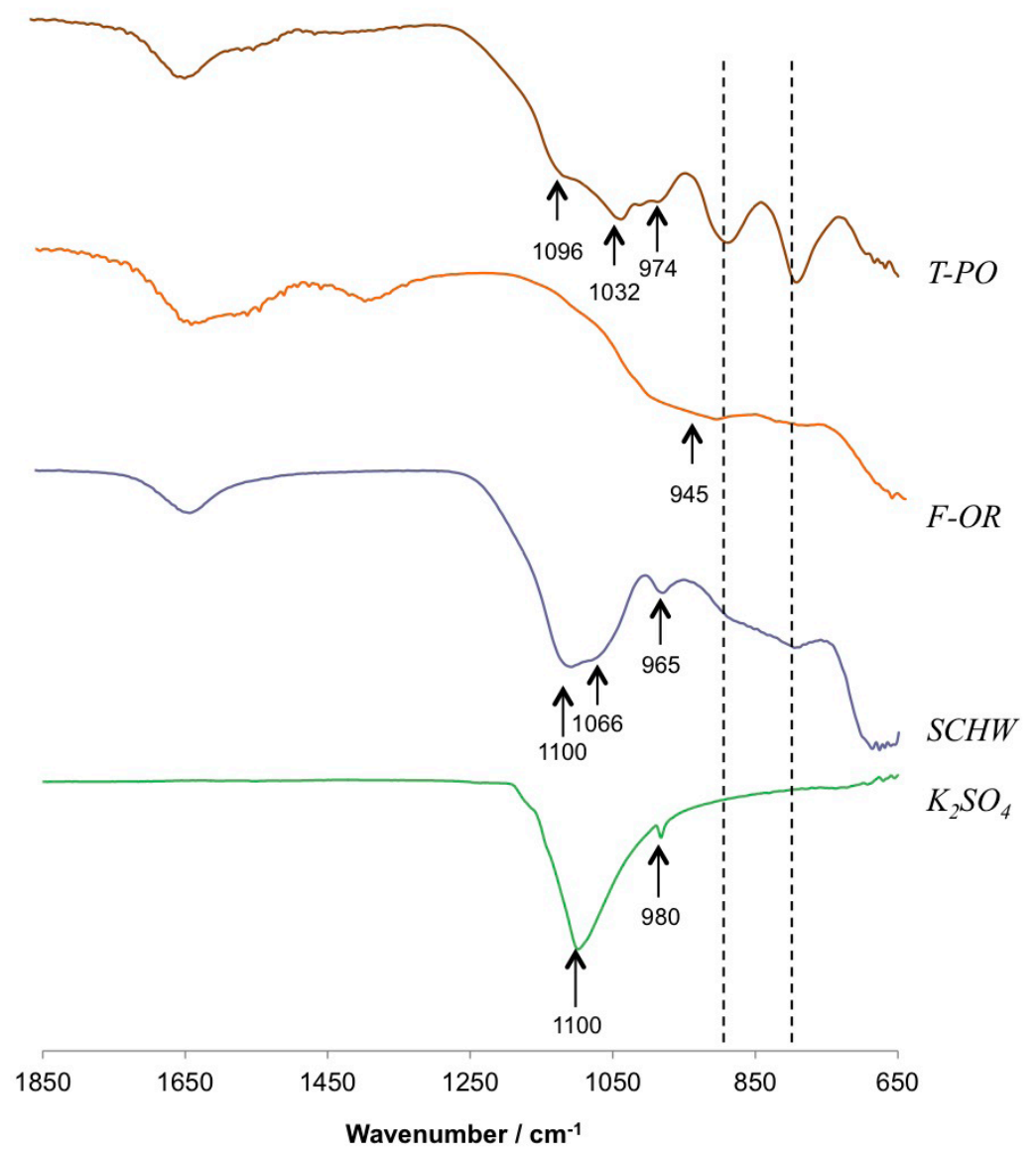

Figure 3. ATR-FTIR spectra of the iron precipitates collected at sampling sites T-PO and F-OR. The spectra of synthetic schwertmannite and $\mathrm{K}_{2} \mathrm{SO}_{4}$ are also shown.
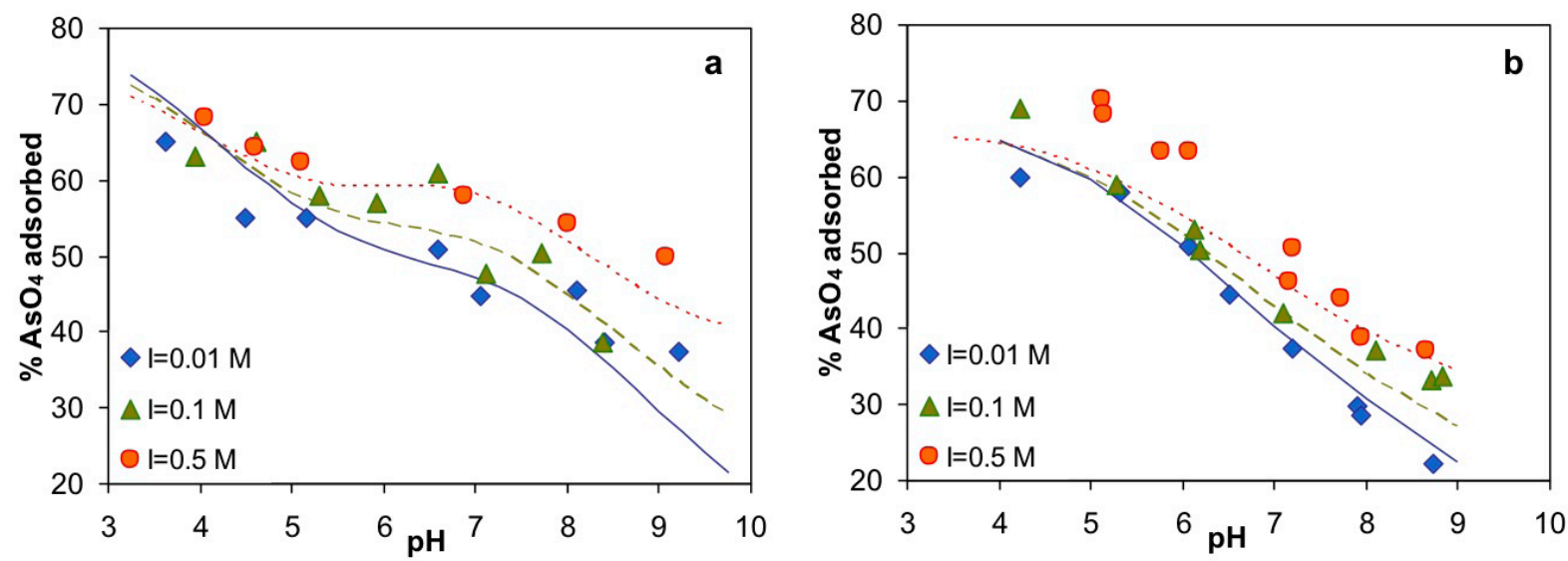

Figure 4. Adsorption envelopes for arsenate in (a) T-PO and (b) F-OR precipitates obtained at different ionic strengths and with an initial arsenate concentration of $570 \mu \mathrm{M}$. Symbols represent the experimental data. Solid, dashed and dotted lines correspond to the simulations of the GTL model at ionic strength $0.01 \mathrm{M}, 0.1 \mathrm{M}$, and $0.5 \mathrm{M}$, respectively. 
arsenate adsorption is rather low at $\mathrm{pH}<5$. A minimal effect of ionic strength at low $\mathrm{pH}$ was previously observed for synthetic goethite and ferrihydrite particles (Antelo et al., 2005, 2010). At $\mathrm{pH}>5$, an increase in ionic strength produces an increase in the adsorption of arsenate on the iron precipitates. Ions that form inner-sphere complexes bind directly to the hydroxyl surface groups via ligand exchange and might not be affected by electrolyte ions or by changes in ionic strength. However, several cases of inner-sphere complexation and increased adsorption with increasing ionic strength have been reported (Rahnemaie et al., 2007; Antelo et al., 2010) and have been attributed to changes in the electrostatic potential at the solid/solution interface. An increase in the ionic strength produces a decrease in the electrostatic repulsion between the charged mineral surface and the arsenate ions, favouring adsorption. The opposite effect may occur at low $\mathrm{pH}$, as an increase in the ionic strength may lower the electrostatic attraction between the positively charged mineral surface and the arsenate ions, minimizing the differences in the adsorption levels at the different ionic strengths.

The adsorption of arsenate on T-PO and F-OR precipitates is compared in Figure 5 for two different arsenate loadings. At the lower $\mathrm{pH}$, adsorption on both precipitates is similar, but at $\mathrm{pH}$ above $5-6$, adsorption on T-PO is higher at both arsenate loadings. The specific surface area of sample F-OR $\left(216 \mathrm{~m}^{2} / \mathrm{g}\right)$ is greater than that of sample T-PO $\left(127 \mathrm{~m}^{2} / \mathrm{g}\right)$ and therefore the former is expected to be more reactive. Nevertheless, as stated above, the structure of sample T-PO partly resembles that of schwertmannite particles, while sample F-OR can be described as ferrihydrite-like. In addition to the surface complexation of arsenate on the surface hydroxyl groups, which is possibly the only adsorption mechanism in sample F-OR, anion exchange reactions may occur in sample T-PO. Another possible explanation for the observed differences in the reactivity of both samples is the presence of co-precipitated trace metals. The T-PO precipitate contains larger amounts of $\mathrm{Cu}$, $\mathrm{Zn}$ and $\mathrm{Ni}$. The presence of trace metals in the crystalline structure may increase the adsorption of arsenate by $20-$ $30 \%$, as already observed for schwertmannite and goethite (Mohapatra et al., 2006; Antelo et al., 2013). The presence of co-precipitated ions and their incorporation in the crystalline structure may lead to changes in the surface properties of the oxides (specific surface area, surface charge and point of zero charge).

\subsection{Copper removal by AMD precipitates}

Copper adsorption on the natural precipitates shows the typical trend observed for metal retention by iron oxides (Jönsson et al., 2006; Ponthieu et al., 2006; Moon and Peacock, 2013) (Figure 6). Thus, the level of adsorption varied from 0 to $100 \%$ within approximately two $\mathrm{pH}$ units. Both iron precipitates exhibited very similar behaviour, with the curves for F-OR shifted slightly towards higher
pH. A previous study by Swedlund and Webster (2001) showed that copper has a higher affinity for synthetic schwertmannite than for synthetic ferrihydrite. These

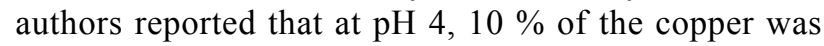
adsorbed on ferrihydrite and $30 \%$ on schwertmannite, and at $\mathrm{pH} 5$ the levels of adsorption were $80 \%$ and $90 \%$, respectively. In the present study, more copper was adsorbed onto the T-PO precipitate (schwertmannite-like) than onto the F-OR precipitate (ferrihydrite-like) at the same $\mathrm{pH}$. This result is consistent with the previous finding for arsenate, which displays a higher affinity for the surface of the T-PO sample. The difference observed in the case of arsenate was explained by the anion exchange reactions between structural sulphate groups and arsenate ions; however, this adsorption mechanism should not contribute to cation binding. Nevertheless, the presence of sulphate in the crystalline structure, along with other co-precipitated ions (Table 2), may alter the surface properties of these iron oxides. Assuming the same site density for iron hydroxyl groups in both precipitates, the observed differences in copper adsorption may be attributed to differences in the protonation constants or the metal affinity constants.

The percentage of $\mathrm{Cu}$ adsorption increased with increasing $\mathrm{pH}$, during which the surface of the precipitates becomes more negatively charged, and with increasing the initial amount of metal ion present. The processes involved in the adsorption of copper by iron oxides have previously been reported (Rodda et al., 1996) and are mainly described as adsorption reactions on the surface - with and without the release of protons and exchange reactions between $\mathrm{Cu}^{2+}$ and $\mathrm{H}^{+}$ions. The $\mathrm{pH}$ dependence is mainly caused by the decrease in competition from protons for the binding sites as the $\mathrm{pH}$ increases. Moreover, electrostatic attraction between the metal cation and the iron hydroxyl groups becomes stronger as the $\mathrm{pH}$ increases, because the surface of the iron oxide becomes more negatively (or less positively) charged.

\subsection{Surface complexation modelling of arsenate and copper immobilization}

\subsubsection{Arsenate modelling}

To describe the experimental results using the GTL model, we assumed that only ligand exchange reactions occurred between the arsenate and the hydroxyl surface groups. In order to minimize the fitting parameters, i.e. parameters that need to be adjusted, anion precipitation and anion exchange reactions were not considered in the modelling calculations. The default values proposed by Dzombak and Morel (1990) for the surface parameters (specific surface area, site density) of hydrous iron oxides were initially considered in the calculations, along with the protonation constants, $\log \mathrm{K}_{\mathrm{H} 1}$ and $\log \mathrm{K}_{\mathrm{H} 2}$. Finally, the values for the arsenate surface complexation constants were initially taken from the database available in Visual MINTEQ, and extra fitting, or adjustment, was conducted when necessary. The arsenate surface complexation 
constants are shown in Table 3, and the corresponding model predictions for adsorption on both iron precipitates are shown in Figures 4 and 5. Use of the default SSA value for hydrous iron oxide $\left(600 \mathrm{~m}^{2} / \mathrm{g}\right)$ in the calculations led to overestimation of the adsorption of arsenate on the precipitates. Although the BET method may underestimate the real surface area of amorphous iron oxides due to the aggregation of particles, the experimental values obtained were considered in the modelling calculations.

As shown in Figure 4b, arsenate adsorption on sample F-OR was reasonably well simulated using the experimental SSA and the default values for the different surface complexation reactions. At the highest ionic strength, I = $0.5 \mathrm{M}$, the complexation parameters slightly underestimated adsorption at lower $\mathrm{pH}$. Although extra fitting of the surface complexation constants improved the model

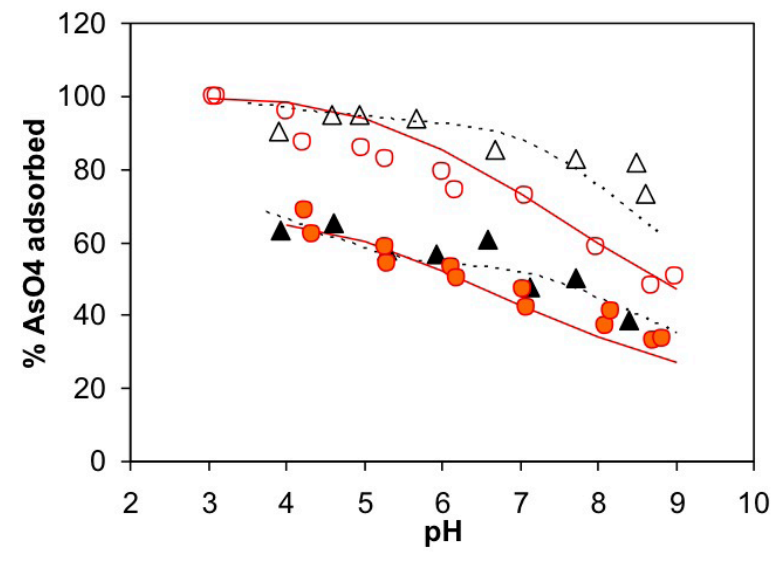

Figure 5. Comparison of arsenate adsorption on F-OR (circles) and T-PO (triangles) precipitates as a function of $\mathrm{pH}$ at ionic strength $0.1 \mathrm{M}$. Filled and empty symbols correspond to an initial arsenate concentration of 570 and $285 \mu \mathrm{M}$, respectively. Solid and dashed lines represent GTL model simulations for F-OR and T-PO precipitates, respectively. estimates at this ionic strength, arsenate adsorption was then overestimated for the other conditions. In the case of sample T-PO, modelling predictions using the experimental SSA $\left(127 \mathrm{~m}^{2} / \mathrm{g}\right)$ underestimated the adsorption of arsenate by $\sim 50 \%$. This is consistent with the existence of an additional adsorption mechanism due to the presence of structural sulphate groups, which are not taken into account in these calculations. As explained above, in order to simplify the calculations, anion exchange reactions were not considered in GTL modelling. Therefore, we assumed that the modelling underestimation is due to an incorrect value of SSA (or site density) and that extra fitting was needed. An SSA of $264 \mathrm{~m}^{2} / \mathrm{g}$ yielded reasonable levels of arsenate adsorption; however, arsenate adsorption was slightly overestimated at $\mathrm{pH}$ below 7 and the effect of ionic strength was minimized when the default complexation constants were used. Additional fitting was conducted to improve the simulations, but the model was only adjusted for the complexation constants of the arsenate surface complexes that contributed to the adsorption at acidic $\mathrm{pH}$ ( $\equiv \mathrm{FeOAsO}(\mathrm{OH})_{2}$ and $\left.\equiv \mathrm{FeOAsO}_{2} \mathrm{OH}\right)$. The fitted constants (see Table 3 ) yielded optimal simulation of the arsenate adsorption on the T-PO precipitate (Figure 4a) throughout the whole $\mathrm{pH}$ range and adequately described the effect of ionic strength. Overall, the GTL model adequately reproduced the adsorption of arsenate on these natural iron precipitates with a minimum number of fitting parameters. However, anion exchange reactions were not taken into account.

In a more realistic approach, $\mathrm{CD}$ model calculations were also conducted by initially assuming that the iron precipitates behave like ferrihydrite particles. Hiemstra and Van Riemsdijk (2009) proposed a ferrihydrite surface model based on goethite, with equal proportions of the crystal faces (110), (001), and (021). Surface site densities of 6 $\mathrm{nm}^{-2}$ and $1.2 \mathrm{~nm}^{-2}$ were considered for the singly and triply coordinated groups respectively, while the SSA determined
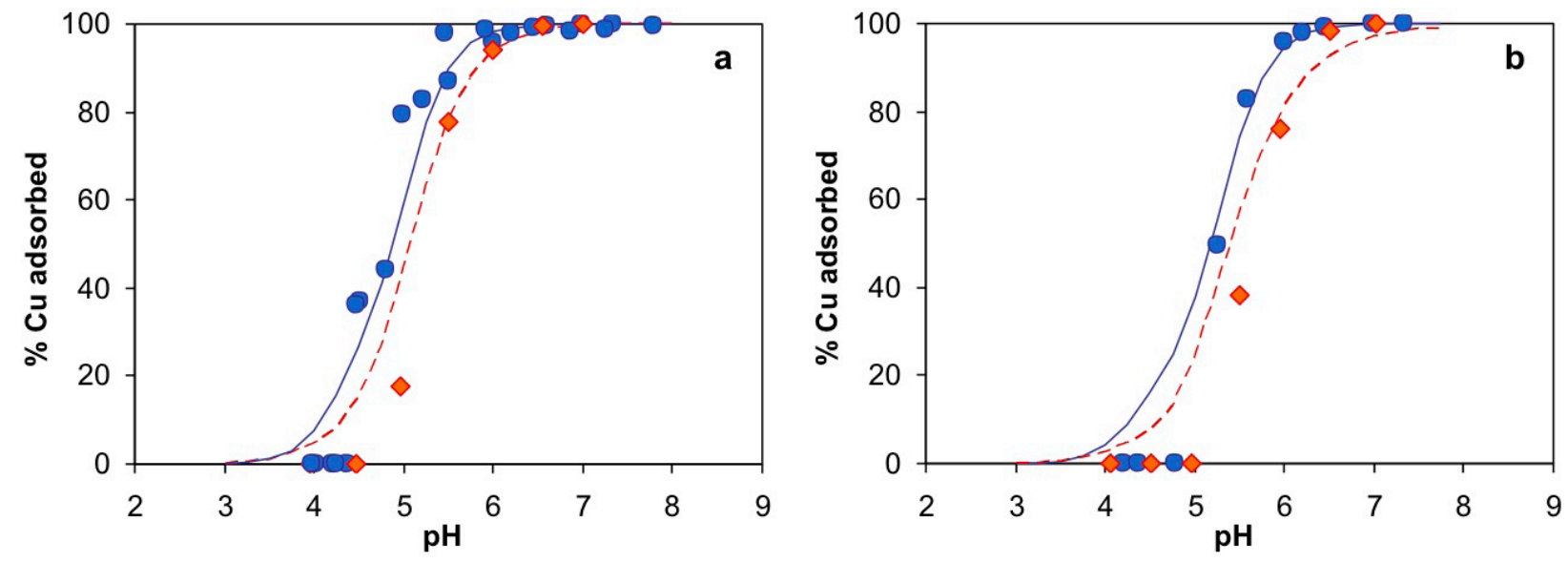

Figure 6. Copper adsorption envelopes in (a) T-PO and (b) F-OR precipitates obtained at two different initial concentrations: $100 \mu \mathrm{M}$ (circles) and $500 \mu \mathrm{M}$ (diamonds), and ionic strength, $0.1 \mathrm{M}$. Solid and dashed lines represent GTL model simulations for the copper loading $100 \mu \mathrm{M}$ and $500 \mu \mathrm{M}$, respectively. 
Table 3. Surface complexes of arsenate considered in the GTL model and the corresponding $\log \mathrm{K}$ values.

\begin{tabular}{lccccc}
\hline Surface complexes & $\mathbf{F e O H}$ & $\mathbf{H}$ & $\mathbf{A s O}_{\mathbf{4}}$ & $\log \boldsymbol{K}(\boldsymbol{F}$-OR $)$ & $\log \boldsymbol{K}(\boldsymbol{T}-\boldsymbol{P O})$ \\
\hline$\equiv \mathrm{FeOAsO}(\mathrm{OH})_{2}$ & 1 & 3 & 1 & $30.98^{\mathrm{a}}$ & $30.20^{\mathrm{b}}$ \\
$\equiv \mathrm{FeOAsO}_{2} \mathrm{OH}$ & 1 & 2 & 1 & $25.84^{\mathrm{a}}$ & $26.04^{\mathrm{b}}$ \\
$\equiv \mathrm{FeOAsO}_{3}$ & 1 & 1 & 1 & $19.50^{\mathrm{a}}$ & $19.50^{\mathrm{a}}$ \\
$\equiv \mathrm{FeOHAsO}_{4}$ & 1 & 0 & 1 & $11.92^{\mathrm{a}}$ & $11.92^{\mathrm{a}}$ \\
\hline
\end{tabular}

Note. Surface site density and protonation constants were set at the values proposed by Dzombak and Morel (1990). The SSA values used in the modelling calculations were 264 and $216 \mathrm{~m}^{2} / \mathrm{g}$ for sample T-PO and F-OR, respectively.

${ }^{a}$ Default constants obtained by Dzombak and Morel (1990).

${ }^{\mathrm{b}}$ Fitted constants.

by BET were used in the calculations. The affinity constants for protons and electrolyte ions were taken from Antelo et al. (2010) and are shown in Table 4. Arsenate adsorption was modelled by assuming the presence of protonated and non-protonated bidentate complexes, because the available data on iron oxides indicates both complexes as predominant (Waychunas et al., 1993; Stachowicz et al., 2006); formation of a protonated monodentate complex was also considered. The surface reactions for the three surface complexes can be formulated as follows:

$$
\begin{aligned}
& \equiv \mathrm{FeOH}^{1 / 2-}+2 \mathrm{H}^{+}+\mathrm{AsO}_{4}^{3-} \leftrightarrows \equiv \mathrm{FeOAsO}_{2} \mathrm{OH}^{3 / 2-}+\mathrm{H}_{2} \mathrm{O} \\
& \equiv 2 \mathrm{FeOH}^{1 / 2-}+2 \mathrm{H}^{+}+\mathrm{AsO}_{4}^{3-} \leftrightarrows \equiv \mathrm{Fe}_{2} \mathrm{O}_{2} \mathrm{AsO}_{2}{ }^{2-}+2 \mathrm{H}_{2} \mathrm{O} \\
& \equiv 2 \mathrm{FeOH}^{1 / 2-}+3 \mathrm{H}^{+}+\mathrm{AsO}_{4}^{3-} \leftrightarrows \equiv \mathrm{Fe}_{2} \mathrm{O}_{2} \mathrm{AsOOH}^{-}+2 \mathrm{H}_{2} \mathrm{O}
\end{aligned}
$$

Arsenate complexation constants previously obtained for goethite (Stachowicz et al., 2006) were used as initial estimates. In the case of the T-PO precipitate, it was not possible to reproduce the arsenate adsorption correctly with the structural parameters of ferrihydrite (Antelo et al., 2010). Adsorption was greatly underestimated across the whole $\mathrm{pH}$ range, indicating both that a higher surface area or surface site density would be necessary, and also that ligand exchange with the surface hydroxyl groups is not the only mechanism controlling the adsorption of arsenate. As explained above, the T-PO precipitate mainly comprises $(\sim 80 \%)$ schwertmannite particles, and therefore the immobilization of arsenate may also involve sulphate anion exchange. This additional adsorption mechanism is specific to schwertmannite, as some of the sulphate groups present in the crystalline structure are weakly bound. Exchange coefficients between $\mathrm{SO}_{4}$ and $\mathrm{AsO}_{4}\left(\mathrm{R}_{\text {ex }}\right)$ were derived by Burton et al. (2009) and by Antelo et al. (2012) for synthetic schwertmannite particles. In both cases, the $\mathrm{R}_{\mathrm{ex}}$ values were lower than $1 \mathrm{~mol}_{\mathrm{SO} 4} / \mathrm{mol}_{\mathrm{AsO} 4}$, which may indicate the existence of both adsorption mechanisms, and the values were $\mathrm{pH}$-dependent. The differences between the $\mathrm{R}_{\mathrm{ex}}$ values for the two synthetic analogues were attributed to differences in the concentrations of outer-sphere sulphate complexes (Antelo et al., 2012).

Assuming that the natural precipitate behaves similarly to the synthetic analogues and that the $\mathrm{R}_{\mathrm{ex}}$ values obtained in both studies are valid, it would be possible to calculate the amount of arsenate exchanged with the sulphate groups in sample T-PO. As $\mathrm{R}_{\mathrm{ex}}$ value and $\mathrm{pH}$ were correlated $\left[\mathrm{r}^{2}\right.$ values of respectively 0.99 and 0.92 were obtained by Antelo et al. (2012) and Burton et al. (2009)], the $\mathrm{R}_{\mathrm{ex}}$ values at the different $\mathrm{pH}$ values considered here can be calculated. Taking into account that the concentration of sulphate groups in sample T-PO $(0.92 \mathrm{mmol} / \mathrm{g})$ is similar to that of the synthetic analogue obtained by Antelo et al. (2012) (1.02 $\mathrm{mmol} / \mathrm{g}$ ), extrapolation of $\mathrm{R}_{\mathrm{ex}}$ at the different $\mathrm{pH}$ values was initially conducted with the observed correlation for this synthetic analogue. At $\mathrm{I}=0.1 \mathrm{M}$, the exchange coefficient ranges from $0.29 \mathrm{mmol}_{\mathrm{SO} 4} / \mathrm{mmol}_{\mathrm{AsO} 4}$ at $\mathrm{pH} 3.94$ to 0.10 $\mathrm{mmol}_{\mathrm{SO} 4} / \mathrm{mmol}_{\mathrm{AsO} 4}$ at $\mathrm{pH} 8.39$. With these $\mathrm{R}_{\mathrm{ex}}$ values, and with the concentration of adsorbed arsenate measured at the different $\mathrm{pH}$ values, it is possible to calculate the amount of arsenate that was exchanged with the sulphate groups present in the T-PO precipitate (Figure 7). As seen in Figure 7a, the sum of the amount of arsenate adsorbed to the hydroxyl groups (simulated with the CD model) and the amount of arsenate exchanged with the sulphate groups (calculated with these $\mathrm{R}_{\mathrm{ex}}$ values) slightly underestimates the adsorption of arsenate. Extrapolation of $\mathrm{R}_{\mathrm{ex}}$ at the different $\mathrm{pH}$ values by considering the correlation reported by Burton et al. (2009) yielded values ranging from 0.56 to $0.31 \mathrm{mmol}_{\mathrm{SO} 4} / \mathrm{mmol}_{\mathrm{AsO} 4}$. Using these $\mathrm{R}_{\mathrm{ex}}$ values to calculate the exchangeable arsenate yields a higher contribution of the anion exchange

Table 4. Surface species and CD model parameters for proton and arsenate adsorption to the surface of the iron precipitates, estimated using the Extended Stern layer model and considering $\mathrm{C} 1=0.74 \mathrm{~F} / \mathrm{m}^{2}$ and $\mathrm{C}_{2}=$ $0.93 \mathrm{~F} / \mathrm{m}^{2} . \Delta \mathrm{z} 0, \Delta \mathrm{z} 1$, and $\Delta \mathrm{z}_{2}$ represent the change of the charge (or charge distribution) in the $0-, 1-$, and 2-planes, respectively.

\begin{tabular}{lcccccc}
\hline Surface reactions & $\equiv \mathbf{F e O H}$ & $\equiv \mathrm{Fe}_{\mathbf{3}} \mathbf{O}$ & $\Delta \mathbf{z}_{\mathbf{0}}$ & $\Delta \mathbf{z}_{\mathbf{1}}$ & $\Delta \mathbf{z}_{\mathbf{2}}$ & $\log \boldsymbol{K}$ \\
\hline$\equiv \mathrm{FeOH}^{1 / 2-}$ & 1 & 0 & 0 & 0 & 0 & $0.00^{\mathrm{a}}$ \\
$\equiv \mathrm{FeOH}_{2}{ }^{1 / 2+}$ & 1 & 0 & 1 & 0 & 0 & $8.70^{\mathrm{a}}$ \\
$\equiv \mathrm{FeOH}^{1 / 2-} \cdots \mathrm{K}^{+}$ & 1 & 0 & 0 & 1 & 0 & $-1.16^{\mathrm{a}}$ \\
$\equiv \mathrm{FeOH}_{2}{ }^{1 / 2+} \cdots \mathrm{NO}_{3}{ }^{-}$ & 1 & 0 & 1 & -1 & 0 & $7.74^{\mathrm{a}}$ \\
$\equiv \mathrm{Fe}_{3} \mathrm{O}^{1 / 2-}$ & 0 & 1 & 0 & 0 & 0 & $0.00^{\mathrm{a}}$ \\
$\equiv \mathrm{Fe}_{3} \mathrm{OH}^{1 / 2+}$ & 0 & 1 & 1 & 0 & 0 & $8.70^{\mathrm{a}}$ \\
$\equiv \mathrm{Fe}_{3} \mathrm{O}^{1 / 2-} \ldots \mathrm{K}^{+}$ & 0 & 1 & 0 & 1 & 0 & $-1.16^{\mathrm{a}}$ \\
$\equiv \mathrm{Fe}_{3} \mathrm{OH}^{1 / 2+} \cdots \mathrm{NO}_{3}{ }^{-}$ & 0 & 1 & 1 & -1 & 0 & $7.74^{\mathrm{a}}$ \\
$\equiv \mathrm{Fe}_{2} \mathrm{O}_{2} \mathrm{AsO}_{2}{ }^{2-}$ & 2 & 0 & 0.47 & -1.47 & 0 & $29.29^{\mathrm{b}}$ \\
$\equiv \mathrm{Fe}_{2} \mathrm{O}_{2} \mathrm{AsOOH}^{-}$ & 2 & 0 & 0.58 & -0.58 & 0 & $32.69^{\mathrm{b}}$ \\
$\equiv \mathrm{FeOAsO}_{2} \mathrm{OH}^{3 / 2-}$ & 1 & 0 & 0.3 & -1.30 & 0 & $26.62^{\mathrm{b}}$ \\
$\equiv(\mathrm{FeOH})_{2} \mathrm{Cu}^{+}$ & 2 & 0 & 0.84 & 1.16 & 0 & $9.18^{\mathrm{c}}$ \\
$\left.\equiv(\mathrm{FeOH})_{2} \mathrm{Cu}^{\mathrm{c}} \mathrm{OH}\right)^{0}$ & 2 & 0 & 0.84 & 0.16 & 0 & $3.60^{\mathrm{c}}$ \\
$\equiv(\mathrm{FeOH})_{2} \mathrm{Cu}_{2}(\mathrm{OH})_{2}{ }^{+}$ & 2 & 0 & 0.84 & 1.16 & 0 & $3.65^{\mathrm{c}}$ \\
$\equiv(\mathrm{FeOH})_{2} \mathrm{Cu}_{2}(\mathrm{OH})_{3}{ }^{0}$ & 2 & 0 & 0.84 & 0.16 & 0 & $-3.10^{\mathrm{c}}$ \\
\hline
\end{tabular}

${ }^{\text {a }}$ From Antelo et al. (2010).

${ }^{\mathrm{b}}$ From Stachowicz et al. (2006).

${ }^{\mathrm{c}}$ From Weng et al. (2008). 
mechanism than in the previous case (Figure 7b) (up to 50 $\%$ of the total adsorbed arsenate). Overall, the sum of the contributions from surface adsorption and anion exchange provides an adequate prediction of the arsenate adsorption in the T-PO precipitates. The exchange coefficients used here were obtained from two schwertmannite analogues with opposite sulphate content. The schwertmannite prepared by Burton et al. (2009), $\mathrm{Fe}_{8} \mathrm{O}_{8}(\mathrm{OH})_{4.80}\left(\mathrm{SO}_{4}\right)_{1.60}$, contained a large amount of outer-sphere complexes that may readily react with arsenate, while the schwertmannite synthesised by Antelo et al. (2012), $\mathrm{Fe}_{8} \mathrm{O}_{8}(\mathrm{OH})_{5.95}\left(\mathrm{SO}_{4}\right)_{1.02}$, mainly comprised inner-sphere complexes, and anion exchange is therefore less likely to occur. This modelling strategy was chosen as initial calculations showed that surface complexation modelling alone could not account for the amount of arsenate adsorbed under the experimental conditions used. Future studies should use a thermodynamic approach to account for the anion exchange reactions. This possibility will be best explored when more spectroscopic and molecular data become available.

Arsenate adsorption onto the F-OR precipitate was reasonably well simulated using the CD model (Figure 8), indicating that surface complexation to the iron hydroxyl groups is the main adsorption mechanism and no additional reactions needed to be considered. Modelling simulations were conducted using the SSA obtained by the BET method, the surface site densities proposed for ferrihydrite particles and with the modelling parameters shown in Table 4. Optimization of the affinity constants may yield better prediction of the arsenate adsorption at the lower $\mathrm{pH}$ values, although for reasons of simplicity no extra fitting was conducted. Figure 8 also shows the abundance of arsenate surface species as a function of $\mathrm{pH}$ according to the $\mathrm{CD}$ model predictions. Under these conditions, the dominant surface species are the bidentate complexes, which are protonated at low $\mathrm{pH}$ and non-protonated at high $\mathrm{pH}$. These calculations showed that the non-protonated bidentate complex is the major surface species at intermediate to high $\mathrm{pH}$. The protonated monodentate complex, at the lower $\mathrm{pH}$ values, contributes to the arsenate adsorption to a lower extent than the protonated bidentate complex, although it makes a higher contribution at relatively high $\mathrm{pH}$.

\subsubsection{Copper modelling}

The adsorption was simulated with the GTL model and, as explained for arsenate modelling, we tried to minimize the number of fitting parameters. We chose this approach because, rather than obtaining a set of complexation constants for each natural sample, we aimed to obtain a general set of constants that could be successfully applied to natural iron precipitates in addition to synthetic iron oxides. In the present modelling approach, cation adsorption is assumed to occur at the two types of surface sites available: high affinity or strong sites $\left(\equiv \mathrm{Fe}^{\mathrm{s}} \mathrm{OH}\right)$ and low affinity or weak sites $\left(\equiv \mathrm{Fe}^{\mathrm{w}} \mathrm{OH}\right)$. The same surface complex stoichiometry is usually considered for both types of site
( $\equiv \mathrm{Fe}^{\mathrm{s}} \mathrm{OCu}^{+}$and $\equiv \mathrm{Fe}^{\mathrm{w}} \mathrm{OCu}^{+}$, respectively). Copper adsorption on the T-PO precipitate was well predicted (Figure 6a, Table 5) using the intrinsic adsorption constants obtained by Dzombak and Morel (1990) for the two surface complexes defined by the GTL model (2.89 and 0.6, respectively). The model-derived SSA obtained in the arsenate modelling $\left(264 \mathrm{~m}^{2} / \mathrm{g}\right)$ was used here. Use of the original SSA proposed by Dzombak and Morel (1990) for hydrous iron oxides $\left(600 \mathrm{~m}^{2} / \mathrm{g}\right)$ overestimated the copper adsorption on both iron precipitates. For the F-OR precipitate, use of the experimental SSA value $\left(216 \mathrm{~m}^{2} / \mathrm{g}\right)$ slightly underestimated the adsorption and additional fitting of the complexation constant was therefore needed. The modelling simulations shown in Figure $6 \mathrm{~b}$ were obtained following optimization of the first adsorption constant $(\log \mathrm{K}=3.19)$, whereas the second constant remained unchanged (Table 5).

The CD model was also used to simulate copper adsorption on T-PO and F-OR precipitates. The intrinsic proton affinities and structural parameters of the precipitates required for $\mathrm{CD}$ model calculations were the same as in the arsenate adsorption modelling. One bidentate surface complex, $(\mathrm{FeOH})_{2} \mathrm{CuOH}$, was initially considered, as proposed by Tiberg et al. (2013), to model copper adsorption on synthetic ferrihydrite, with a charge distribution between the 0 -plane and the 1-plane, $\Delta \mathrm{z}_{0}=0.5$ and $\Delta \mathrm{z}_{1}=0.5$, and a $\log \mathrm{K}=0.97$. Adsorption of copper on T-PO and F-OR was greatly underestimated by the model. However, further optimization of the surface complex constant was not sufficient to improve the model prediction. This appears reasonable if we consider the difference between the SSA reported by Tiberg et al. (2013) for ferrihydrite $\left(650 \mathrm{~m}^{2} / \mathrm{g}\right)$ and the experimental SSA measured for T-PO $\left(127 \mathrm{~m}^{2} / \mathrm{g}\right)$ and F-OR $\left(216 \mathrm{~m}^{2} / \mathrm{g}\right)$. Only a significant increase in the SSA of the precipitates, far from their BET values, would lead to a better description of the copper adsorption on the natural precipitates.

In the next step, the surface complexes postulated by Weng et al. (2008) for describing $\mathrm{Cu}$ adsorption on goethite were used (Figure 9). Four bidentate inner-sphere complexes were considered between copper and the singly coordinated surface sites of the goethite, allowing for hydrolysis and dimer formation in copper surface species. The stoichiometry of the surface species and the charge distribution between the planes that comprise the solid/solution interface are shown in Table 4 and the corresponding surface reactions are:

$$
\begin{aligned}
& \equiv 2 \mathrm{FeOH}^{1 / 2-}+\mathrm{Cu}^{2+} \leftrightarrows \equiv(\mathrm{FeOH})_{2} \mathrm{Cu}^{+} \\
& \equiv 2 \mathrm{FeOH}^{1 / 2-}+\mathrm{Cu}^{2+}+\mathrm{H}_{2} \mathrm{O} \leftrightarrows \equiv(\mathrm{FeOH})_{2} \mathrm{Cu}(\mathrm{OH})^{0}+\mathrm{H}^{+} \\
& \equiv 2 \mathrm{FeOH}^{1 / 2-}+2 \mathrm{Cu}^{2+}+2 \mathrm{H}^{2} \mathrm{O} \leftrightarrows \equiv(\mathrm{FeOH})_{2} \mathrm{Cu}_{2}(\mathrm{OH})^{2+}+2 \mathrm{H}^{+} \\
& \equiv 2 \mathrm{FeOH}^{1 / 2-}+2 \mathrm{Cu}^{2+}+3 \mathrm{H}_{2} \mathrm{O} \leftrightarrows \equiv(\mathrm{FeOH})_{2} \mathrm{Cu} 2(\mathrm{OH})_{3}{ }^{0}+3 \mathrm{H}^{+}
\end{aligned}
$$

Combining these complexation constants and the specific 

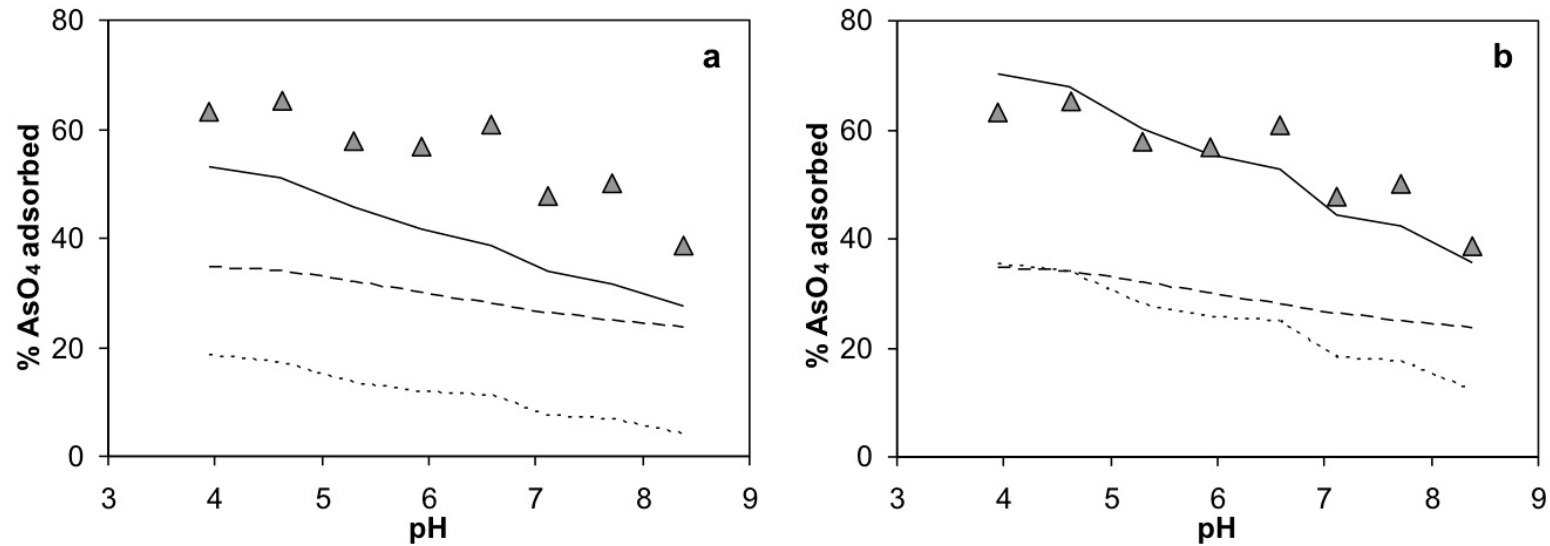

Figure 7. Arsenate adsorption envelope on T-PO precipitate at ionic strength $0.1 \mathrm{M}$, an initial arsenate concentration of $570 \mu \mathrm{M}$ and with $\mathrm{R}_{\mathrm{ex}}$ values taken from (a) Antelo et al. (2012) and (b) Burton et al. (2009). Triangles correspond to the experimental data, while solid, dotted and dashed lines represent the total adsorption of arsenate, the amount of arsenate exchanged with the structural sulphate groups, and the amount of arsenate adsorbed to the hydroxyl surface groups calculated with the CD model for ferrihydrite, respectively.

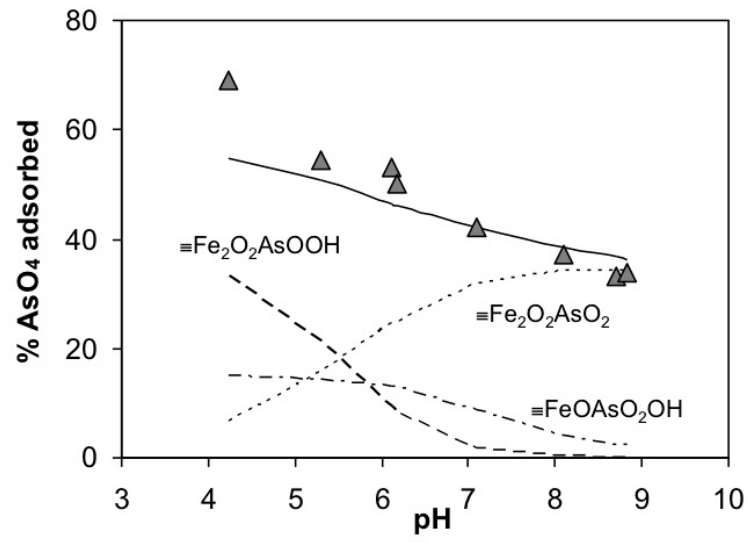

Figure 8. Adsorption envelope for arsenate in F-OR precipitate, at ionic strength $0.1 \mathrm{M}$ and with an initial arsenate concentration of $570 \mu \mathrm{M}$. Triangles correspond to the experimental data, solid lines correspond to $\mathrm{CD}$ model predictions and dashed, dotted and dot-dashed lines correspond to the arsenate surface species $\equiv \mathrm{Fe}_{2} \mathrm{O}_{2} \mathrm{AsOOH}, \equiv \mathrm{Fe}_{2} \mathrm{O}_{2} \mathrm{AsO}_{2}$ and $\equiv \mathrm{FeOAsO}_{2} \mathrm{OH}$, respectively.

Table 5. Surface complexes of $\mathrm{Cu}$ considered in the GTL model and the corresponding $\log \mathrm{K}$ values.

\begin{tabular}{ccccccc}
\hline $\begin{array}{c}\text { Surface } \\
\text { complexes }\end{array}$ & $\mathrm{Fe}^{\mathrm{s}} \mathrm{OH}$ & $\mathrm{Fe}^{\mathrm{w}} \mathrm{OH}$ & $\mathrm{H}$ & $\mathrm{Cu}$ & $\log \boldsymbol{K}(\boldsymbol{T}-\boldsymbol{P O})$ & $\log \boldsymbol{K}(\boldsymbol{F}-\boldsymbol{O} \boldsymbol{R})$ \\
\hline$\equiv \mathrm{Fe}^{\mathrm{s}} \mathrm{OCu}^{+}$ & 1 & 0 & -1 & 1 & $2.89^{\mathrm{a}}$ & $3.19^{\mathrm{b}}$ \\
$\equiv \mathrm{Fe}^{\mathrm{w}} \mathrm{OCu}^{+}$ & 0 & 1 & -1 & 1 & $0.60^{\mathrm{a}}$ & $0.60^{\mathrm{a}}$ \\
\hline
\end{tabular}

${ }^{a}$ Default constant obtained by Dzombak and Morel (1990).

${ }^{\mathrm{b}}$ Fitted constant.

parameters for the natural iron oxides yielded a good description of $\mathrm{Cu}$ adsorption on sample T-PO at $\mathrm{pH}>5$, whereas the adsorption was overestimated at lower $\mathrm{pH}$. The modelling was finally improved by fitting one of the constants. The decision about which complexation constant should be fitted was based on the distribution of the four surface complexes, which indicated that $\equiv(\mathrm{FeOH})_{2} \mathrm{Cu}(\mathrm{OH})$

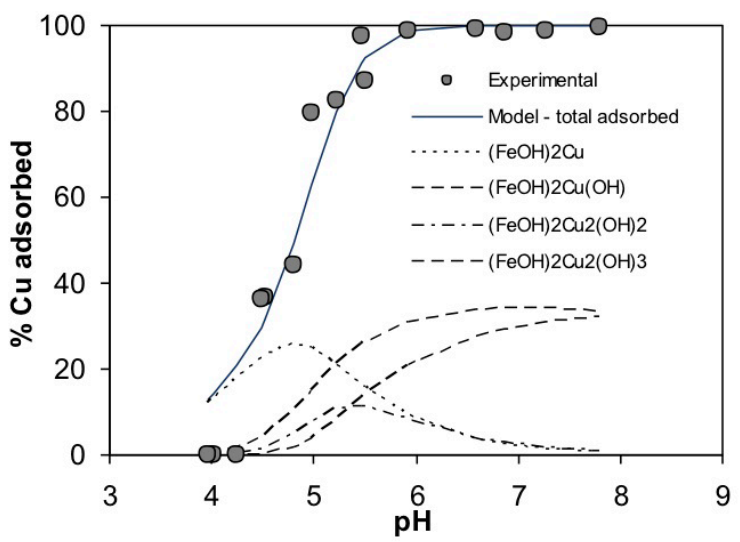

Figure 9. $\mathrm{Cu}$ adsorption envelope and surface speciation on T-PO. Symbols represent experimental data at $[\mathrm{Cu}]=100 \mu \mathrm{M}$, and lines represent the adsorption percentage of the four surface complexes according to the CD model.

was the predominant species at the $\mathrm{pH}$ range where the model overestimated the copper adsorption $(\mathrm{pH}<5)$. The fitted value of $\log \mathrm{K}$ for the $\equiv(\mathrm{FeOH})_{2} \mathrm{Cu}(\mathrm{OH})$ complex was 2.55 instead of 3.60. Although adsorption on sample F-OR was slightly overestimated throughout the entire $\mathrm{pH}$ range, irrespectively of whether the complexation constants were those proposed by Weng et al. (2008) or the fitted constants that described the adsorption on T-PO, no further fitting was done. As stated above, the idea of this modelling exercise was to simulate the adsorption on the iron precipitates using model parameters derived for synthetic analogues. Ideally, no fitting would be necessary.

Analysis of the distribution of the total percentage of adsorption across the different surface complexes shows that $\equiv(\mathrm{FeOH})_{2} \mathrm{Cu}$ species dominate at $\mathrm{pH}<5.2$. From this $\mathrm{pH}$ onwards $\equiv(\mathrm{FeOH})_{2} \mathrm{Cu}(\mathrm{OH})$ is the dominant species, although the other two hydroxylated forms also become important (Figure 9). This distribution of surface species 
is in agreement with that found by Weng et al. (2008). Modelling simulations on goethite showed that the monomer bidentate inner-sphere species is important at low $\mathrm{pH}$, whereas the hydrolysed monomer bidentate species dominates at higher $\mathrm{pH}$.

\section{Conclusions}

The findings of the present study suggest that the natural iron precipitates behave similarly to synthetic analogues. The iron-rich precipitates collected at two sites affected by AMD occurred as mixtures of varying proportions of schwertmannite-, goethite-, and ferrihydrite-like particles. The dominant mineralogy of the precipitates changed in the two sampling sites due to the differences in the water chemistry and the overall impact by AMD. The iron-rich bed sediments collected at the copper mine site (T-PO), which is greatly affected by AMD, were mainly constituted by amorphous schwertmannite $(\sim 78 \%)$ and goethite-like $(\sim 22$ $\%)$ particles. The loose precipitate collected in the sampling site close to the tungsten and tin mine (F-OR) was slightly affected by AMD and the mineralogy was dominated by the presence of ferrihydrite or amorphous iron oxides.

The arsenate and copper adsorption experiments carried out showed that mobility of these two trace elements was mainly governed by the presence of the iron oxides. Adsorption trends for both elements are identical to those found for their synthetic analogues, but the adsorption levels were always greater in the precipitates collected in the sampling site that was more affected by AMD. The main difference between the two iron precipitates is the existence of structural sulphate groups in the sample resembling schwertmannite, for which the arsenate adsorption process is controlled by two mechanisms: surface complexation with the iron hydroxyl groups and anion exchange with the structural sulphate groups present in the mineral particles. For copper, adsorption mechanisms should be the same for both precipitates, and differences can be assigned to the differences in the proton or metal affinity caused by the presence of metal impurities and sulphate ions. These adsorption mechanisms may be confirmed in the future by conducting a detailed surface chemical analysis with spectroscopic techniques.

The experimental results obtained for arsenate and copper were satisfactorily simulated with the GTL and the CD models. Despite the fact that the nature of the iron precipitates has been demonstrated to be different, most of the surface parameters available in the literature for synthetic iron oxides could be used as initial estimates. The good modelling predictions obtained at the different experimental conditions for both arsenate and copper adsorption indicate that using these estimates, obtained either for ferrihydrite or goethite, is a suitable approach. In general, the model simulations could be improved if additional fitting of the SSA or surface complexation constants was conducted. Among the two SCM studied, the CD model represents a more realistic approach, allowing the determination of the arsenate and copper surface species formed. Finally, if the sulphate-arsenate exchange coefficients obtained for synthetic analogues are considered, it is possible to determine the contribution of both anion exchange and surface complexation in the adsorption process of arsenate on the iron precipitates resembling schwertmannite. Although this is a simple approach, and the obtained results are promising, future studies should focus on the formulation of a thermodynamic approach to describe the anion exchange reactions.

\section{Acknowledgements}

The present work was financially supported by the Ministerio de Ciencia e Innovación under research project CTM2011-24985 and by the Xunta de Galicia under the research project EM2013/040. The authors thank Pilar Bermejo of the Department of Analytical Chemistry, Nutrition, and Bromatology of the University of Santiago de Compostela for the ICP-OES measurements and Alvaro Gil from the Ceramic Institute of the USC for the BET measurements. We thank Darío de la Iglesia and Carla Otero for their experimental work. We also acknowledge the assistance of Felipe Macías-García, Cristina Pastoriza, and María Santiso during the collection and the characterization of the samples. We thank two anonymous reviewers for their comments and suggestions, and guest editor Mario Villalobos for his time and effort.

\section{References}

Acero, P., Ayora, C., Torrentó, C., Nieto, J.M., 2006, The behaviour of trace elements during schwertmannite precipitation and subsequent transformation into goethite and jarosite: Geochimica et Cosmochimica Acta, 70, 4130-4139.

Álvarez, E., Pérez, A., Calvo, R., 1993, Aluminium speciation in surface waters and soil solutions in areas of sulphide mineralization in Galicia (N.W. Spain): Science of the Total Environment, 133, 17-37.

Álvarez, E., Fernández-Sanjurjo, M., Otero, X.L., Macías, F., 2011, Aluminum speciation in the bulk and rhizospheric soil solution of the species colonizing an abandoned copper mine in Galicia (NW Spain): Journal of Soils and Sediments, 11, 221-230.

Antelo, J., Avena, M., Fiol, S., López, R., Arce, F., 2005, Effects of pH and ionic strength on the adsorption of phosphate and arsenate at the goethite-water interface: Journal of Colloid and Interface Science, 285, 476-486.

Antelo, J., Fiol, S., Pérez, C., Mariño, S., Arce, F., Gondar, D., López, R., 2010, Analysis of phosphate adsorption onto ferrihydrite using the CD-MUSIC model: Journal of Colloid and Interface Science, 347, 112-119.

Antelo, J., Fiol, S., Gondar, D., López, R., Arce, F., 2012, Comparison of arsenate, chromate and molybdate binding on schwertmannite: Surface adsorption vs anion-exchange: Journal of Colloid and Interface Science, 386, 338-343.

Antelo, J., Fiol, S., Gondar, D., Pérez, C., López, R., Arce, F., 2013, Cu(II) incorporation to schwertmannite: Effect on stability and reactivity under AMD conditions: Geochimica et Cosmochimica Acta, 119, 
149-163.

Asta, M.P., Ayora, C., Román-Ross, G., Cama, J., Acero, P., Gault, A.G., Charnock, J.M., Bardelli, F., 2010, Natural attenuation of arsenic in the Tinto Santa Rosa acid stream (Iberian Pyritic Belt, SW Spain): The role of iron precipitates: Chemical Geology, 271, 1-12.

Bigham, J.M., Schwertmann, U., Carlson, L., Murad, E., 1990, A poorly crystallized oxyhydroxisulfate of iron formed by bacterial oxidation of $\mathrm{Fe}(\mathrm{II})$ in acid mine waters: Geochimica et Cosmochimica Acta $54,2743-2758$.

Bigham, J.M., Schwertmann, U., Traina, S.J., Winland, R.L., Wolf, M., 1996, Schwertmannite and the chemical modeling of iron in acid sulfate waters: Geochimica et Cosmochimica Acta, 60, 2111-2121.

Bigham, J.M., Nordstrom, D.K., 2000, Iron and aluminium hydroxysulfates from acid sulphate waters, in Alpers, C.N., Jambor, J.L., Nordstrom, D.K. (eds.), Reviews in mineralogy and geochemistry - Sulfate minerals: Crystallography, geochemistry, and environmental significance: Washington, DC, The Mineralogical Society of America, 351-403 pp.

Burgos, W.D., Borch, T., Troyer, L.D., Luan, F., Larson, L.N., Brown, J.F., Lambson, J., Shimizu, M., 2012, Schwertmannite and Fe oxides formed by biological low-pH Fe(II) oxidation versus abiotic neutralization: Impact of trace metal sequestration: Geochimica et Cosmochimica Acta, 76, 29-44.

Burton, E.D., Bush, R.T., Johnston, S.G., Watling, K.M., Hocking, R.K., Sullivan, L.A., Parker, G.K., 2009, Sorption of arsenic(V) and arsenic(III) to schwertmannite: Environmental Science \& Technology, 43, 9202-9207.

Caraballo, M.A., Rimstidt, J.D., Macías, F., Nieto, J.M., Hochella Jr., M.F., 2013, Metastability, nanocrystallinity and pseudo-solid solution effects on the understanding of schwertmannite solubility: Chemical Geology, 360-361, 22-31.

Carlson, L., Bigham, J.M., Schwertmann, U., Kyek, A., Wagner, F., 2002, Scavenging of As from acid mine drainage by schwertmannite and ferrihydrite: A comparison with synthetic analogues: Environmental Science \& Technology, 36, 1712-1719.

Clesceri, L.S., Greenberg, A.E., Eaton, A.D., 1998, Standard Methods for the Examination of Water and Wastewater: Washington, DC, USA, American Public Health Association, 1220 p.

Cornell, R.M, Schwertmann, U., 1996, The Iron Oxides: Structure, Properties, Reactions, Occurrences and Uses: New York, USA, $\mathrm{VCH}, 573 \mathrm{p}$.

Davis, J.A., James, R.O., Leckie, J.O., 1978, Surface ionization and complexation at the oxide/water interface. I. Computation of electrical double layer properties in simple electrolytes: Journal of Colloid and Interface Science, 63, 480-499.

Dzombak, D.A, Morel, F.M.M., 1990, Surface Complexation Modeling. Hydrous Ferric Oxide: New York, USA, John Wiley \& Sons, 416 p.

European Commission, 1998, Council Directive 98/83/EC of 3 November 1998 on the quality of water intended for human consumption: Official Journal of European Union L, 330, pp. 32-54.

Fukushi, K., Aoyama, K., Yang, C., Kitadai, N., Nakashikma, S., 2013, Surface complexation modeling for sulfate adsorption on ferrihydrite consistent with in situ infrared spectroscopic observations: Applied Geochemistry, 36, 92-103.

Groenenberg, J.A., Lofts, S., 2014, The use of assemblage models to describe trace element partitioning, speciation, and fate: A review: Environmental Toxicology and Chemistry, 33, 2181-2196.

Gustafsson, J.P., 2012, Visual MINTEQ 3.0: Available from http://vminteq. lwr.kth.se/

Hiemstra T., van Riemsdijk W.H., 1996, A surface structural approach to ion adsorption: the charge distribution (CD) model; Journal of Colloid and Interface Science, 179, 488-508.

Hiemstra, T., van Riemsdijk, W.H., 2009, A surface structural model for ferrihydrite I: Sites related to primary charge, molar mass, and mass density: Geochimica et Cosmochimica Acta, 73, 4423-4436.

Jönsson, J., Sjöberg, S., Lövgren, L., 2006, Adsorption of $\mathrm{Cu}(\mathrm{II})$ to schwertmannite and goethite in presence of dissolved organic matter: Water Research, 40, 969-974.
Karamalidis, A.K., Dzombak, D.A., 2010, Surface Complexation Modeling: Gibbsite: New Jersey, USA, John Wiley \& Sons.

Keizer, M.G., van Riemsdijk, W.H., 1998, ECOSAT: Equilibrium Calculation of Speciation and Transport: Wageningen, The Netherlands, Department Soil Science and Plant Nutrition, Wageningen Agricultural University, Technical Report, 76 p.

Kumpulainen, S., Carlson, L., Räisänen, M.L., 2007, Seasonal variation of ochreous precipitates in mine effluents in Finland: Applied Geochemistry, 22, 760-777.

Lee, G., Bigham, J.M., Faure, G., 2002, Removal of trace elements by coprecipitation with $\mathrm{Fe}, \mathrm{Al}$ and $\mathrm{Mn}$ from natural waters contaminated with acid mine drainage in the Ducktown Mining District, Tennessee: Applied Geochemistry, 17, 569-581.

Lenoble, V., Deluchat, V., Serpaud, B., Bollinger, J.C., 2003, Arsenite oxidation and arsenate determination by the molybene blue method: Talanta, 61, 267-276.

Maillot, F., Morin, G., Julliot, F., Bruneel, O., Casiot, C., Ona-Nguema, G., Wang, Y., Lebrun, S., Aubry, E., Vlaic, G., Brown Jr., G.E., 2013, Structure and reactivity of As(III)- and As(V)-rich schwertmannites and amorphous ferric arsenate sulfate from the Carnoulès acid mine drainage, France: Comparison with biotic and abiotic model compounds and implications for As remediation: Geochimica et Cosmochimica Acta, 104, 310-329.

Martínez, C.E., McBride, M.B., 2001, Cd, Cu, Pb, and $\mathrm{Zn}$ coprecipitates in $\mathrm{Fe}$ oxide formed at different $\mathrm{pH}$ : Aging effects on metal solubility and extractability by citrate: Environmental Toxicology and Chemistry, 20, 122-126.

Mathur, S.S., Dzombak, D.A., 2006, Surface complexation modeling: Goethite, in Lützenkirchen, J. (ed.), Interface science and technology - Surface complexation: Amsterdam, The Netherlands, Academic Press, pp. 443-468.

McKeague, J.A., Day, J.H., 1966, Dithionite- and oxalate-extractable Fe and $\mathrm{Al}$ as aids in differentiating various classes of soils: Canadian Journal of Soil Science, 46, 13-22.

Mohapatra, M., Sahoo, S.K., Anand, S., Das, R.P., 2006, Removal of As(V) by $\mathrm{Cu}(\mathrm{II})-, \mathrm{Ni}(\mathrm{II})-$, or $\mathrm{Co}(\mathrm{II})$-doped goethite samples: Journal of Colloid and Interface Science, 298, 6-12.

Moon, E.M., Peacock, C.L., 2013, Modelling Cu(II) adsorption to ferrihydrite and ferrihydrite-bacteria composites: Deviation from additive adsorption in the composite sorption system: Geochimica et Cosmochimica Acta, 104, 148-164.

Nordstrom, D.K., 2011, Mine waters: Acid to circumneutral: Elements, 7, 393-398.

Olías, M., Cánovas, C.R., Nieto, J.M., Sarmiento, A.M., 2006, Evaluation of the dissolved contaminant load transported by the Tinto and Odiel rivers (South West Spain): Applied Geochemistry, 21, 1733-1749.

Paikaray, S., Göttlicher, J., Peiffer, S., 2011, Removal of As(III) from acidic waters using schwertmannite: Surface speciation and effect of synthesis pathway: Chemical Geology, 283, 134-142.

Paikaray, S., Göttlicher, J., Peiffer, S., 2012, As(III) retention kinetics, equilibrium and redox stability on biosynthesized schwertmannite and its fate and control on schwertmannite stability on acidic $(\mathrm{pH}$ 3.0) aqueous exposure: Chemosphere, 86, 557-564.

Peak, D., Ford, R.G., Sparks, D.L., 1999, An in situ ATR-FTIR investigation of sulphate bonding mechanisms on goethite: Journal of Colloid and Interface Science, 218, 289-299.

Peretyazko, T., Zachara, J.M., Boily, J.F., Xia, Y., Gassman, P.L., Arey, B.W., Burgos, W.D., 2009, Mineralogical transformation controlling acid mine drainage chemistry: Chemical Geology, 262, 169-178.

Ponthieu, M., Julliot, F., Hiemstra, T., van Riemsdijk, W.H., Benedetti, M.F., 2006, Metal ion binding to iron oxides: Geochimica et Cosmochimica Acta, 70, 2679-2698.

Rahnemaie, R., Hiemstra, T., van Riemsdijk, W.H., 2007, Geometry, charge distribution, and surface speciation of phosphate on goethite: Langmuir, 23, 3680-3689.

Regenspurg, S., Brand, A., Peiffer, S., 2004, Formation and stability of schwertmannite in acidic mining lakes: Geochimica et Cosmochimica Acta, 68, 1185-1197. 
Regenspurg, S., Peiffer S., 2005, Arsenate and chromate incorporation in schwertmannite: Applied Geochemistry, 20, 1226-1239.

Rodda, D.P., Wells, J.D., Johnson B.B., 1996, Anomalous adsorption of copper(II) on goethite: Journal of Colloid and Interface Science, 184, 564-569.

Schroth, A.W., Parnell Jr., R.A., 2005, Trace metal retention through the schwertmannite to goethite transformation as observed in a field setting, Alta Mine, MT: Applied Geochemistry, 20, 907-917.

Stachowicz, M., Hiemstra, T., van Riemsdijk, W.H., 2006, Surface speciation of $\mathrm{As}(\mathrm{III})$ and $\mathrm{As}(\mathrm{V})$ in relation to charge distribution: Journal of Colloid and Interface Science, 302, 62-75.

Swedlund, P.J., Webster, J.G., 2001, Cu and Zn ternary surface complex formation with SO4 on ferrihydrite and schwertmannite: Applied Geochemistry, 16, 503-511.

Tiberg, C., Sjösdest, C., Persson, I., Gustafsson, J.P., 2013, Phosphate effects on copper(II) and lead(II) sorption to ferrihydrite: Geochimica et Cosmochimica Acta, 120, 140-157.

Tresintsi, S., Simeonidis, K., Pliatsikas, N., Vourlias, G., Patsalas, P., Mitrakas, M., 2014, The role of $\mathrm{SO}_{4}^{2-}$ surface distribution in arsenic removal by iron oxy-hydroxides: Journal of Solid State Chemistry, $213,145-151$.
Waychunas, G.A., Rea, B.A., Fuller, C.C., Davis, J.A., 1993, Surface chemistry of ferrihydrite: Part 1. EXAFS studies of the geometry of coprecipitated and adsorbed arsenate: Geochimica et Cosmochimica Acta, 57, 2251-2269.

Weng, L., van Riemsdijk, W.H., Hiemstra, T., 2008, $\mathrm{Cu}^{2+}$ and $\mathrm{Ca}^{2+}$ adsorption to goethite in the presence of fulvic acids: Geochimica et Cosmochimica Acta, 72, 5857-5870.

Zhang, G.Y., Peak, D., 2007, Studies of Cd(II)-sulfate interaction at the goethite-water interface by ATR-FTIR spectroscopy: Geochimica et Cosmochimica Acta, 71, 2158-2169.

Zhu, J., Pigna, M., Cozzolino, V., Caporale, A.G., Violante, A., 2011, Sorption of arsenite and arsenate on ferrihydrite: Effect of organic and inorganic ligands: Journal of Hazardous Materials, 189, 564-571.

Manuscript received: October 21, 2014

Corrected manuscript received: January 8, 2015

Manuscript accepted: January 16, 2015 